\title{
Estimation of The Effect of Rain and Incidents on Freeway Capacity and Free-Flow Speed
}

\author{
By \\ (C) 2019
}

Abdulmajeed Alsharari

B.Sc. Civil Engineering, Aljouf University, 2015

Submitted to the graduate degree program in Civil, Environmental, and Architectural

Engineering and the Graduate Faculty of the University of Kansas in partial fulfillment of the requirements

for the degree of Master of Science in Civil Engineering.

Chair: Dr. Alexandra Kondyli

Dr. Steven D. Schrock

Dr. Thomas E. Mulinazzi

Date Defended: 30 May 2019 
The thesis committee for Abdulmajeed Alsharari certifies that this is the approved version of the following thesis:

\section{Estimation of the Effect of Rain and Incidents on Freeway Capacity and Free-Flow Speed}

Chair: Dr. Alexandra Kondyli

Date Approved: 9 June 2019 


\section{Abstract}

The goal of this thesis was to examine the effect of incidents and adverse weather (rain) on capacity and Free-Flow Speed (FFS). Data were collected from multiple freeway segments in Kansas City, Kansas from 2014 to 2018. In this thesis, capacities and free-flow speed were measured during four conditions: (1) base conditions, (2) adverse weather only, (3) incidents only, and (4) adverse weather and incidents.

Freeway flow breakdown was assumed to occur when speed dropped below $75 \%$ of the FreeFlow Speed. This definition was used for measuring capacity during non-incident conditions. Average discharge flow, i.e., the flow after the breakdown and during congested conditions with duration of at least 15 minutes, was used to identify capacity under incidents conditions.

Capacity Adjustment Factors (CAF), and Speed Adjustment Factors (SAF) were established in this thesis to identify the remaining capacity or the Free-Flow Speed reduction during an incident or adverse weather conditions. CAFs were found by comparing the average capacity during base conditions to the average capacity during adverse weather (rain), incidents, or adverse weather and incidents. Likewise, SAFs were estimated by comparing average FFS during base conditions and average FFS during rain, incident, or rain and incidents. CAFs and SAFs were primarily developed for use within the 6th edition of Highway Capacity Manual (HCM6); although the manual does not provide SAFs for incidents. Also, the effect of incidents along with rain on capacity and FFS is assumed to be additive in the HCM6, but this assumption has not been validated with actual data.

The results from this thesis indicated that rain has minimal effect on capacity. Also, only FFS on three-lanes freeways was impacted by rain. It was also found that incidents and incidents during rain had an impact on capacity and FFS. The measurement location with respect to the closure 
during incidents was considered in this research. However, according to the statistical analysis, the location was found to be significant only for incidents during rainy conditions, and only at freeways with two and three lanes. 


\section{ACKNOWLEDGMENTS}

I would first like to thank my thesis advisor Dr. Alexandra Kondyli. Her advice and guidelines were constructive whenever I ran into a trouble spot or had a question about my research or writing. She allowed this paper to be in better shape by steering me in the right direction whenever she thought I needed it.

Also, I would also like to acknowledge Dr. Steven D. Schrock and Dr. Thomas E. Mulinazzi, for agreeing to be part of my committee and for offering valuable insights from their experience in transportation engineering.

I want to express my very profound gratitude to my parents, my father Saleh and my mother Norah Alsharari, for providing me with unfailing support and continuous encouragement throughout my years of study.

Finally, I would like to thank my family: my wife Nada Alsharari, and to my fabulous son (Alwaleed) for supporting me spiritually throughout my study journey and writing this thesis. This accomplishment would not have been possible without them. 


\section{Table of Contents}

Estimation of The Effect of Rain and Incidents on Freeway Capacity and Free-Flow Speed ... i

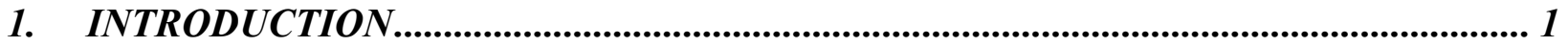

1.1. Problem Statement ........................................................................................................... 1

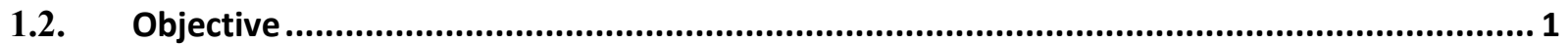

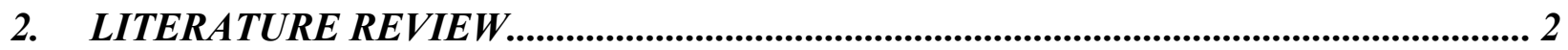

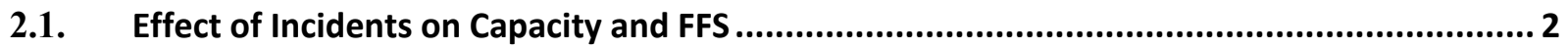

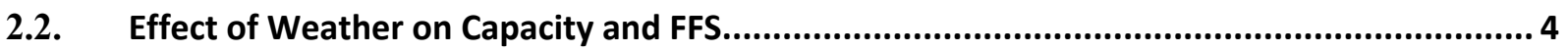

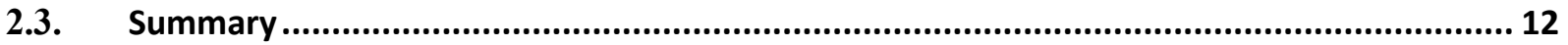

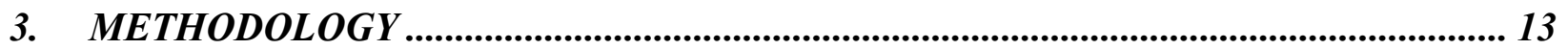

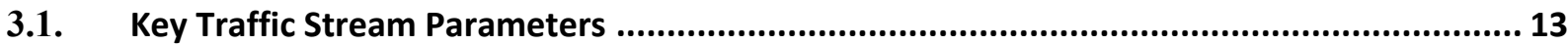

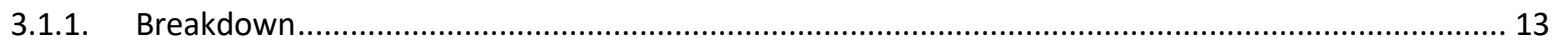

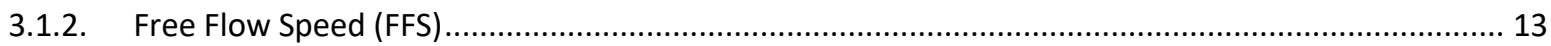

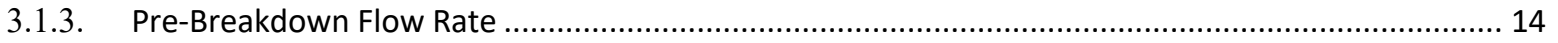

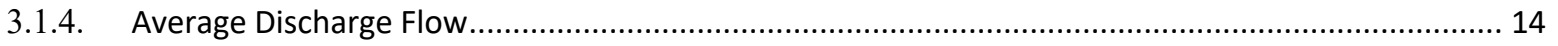

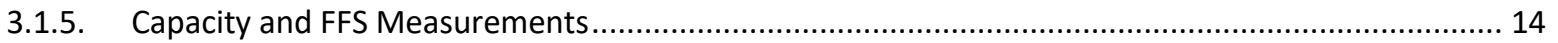

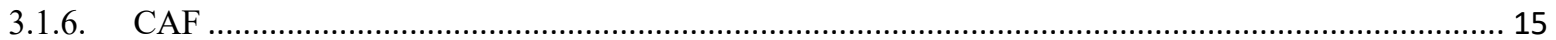

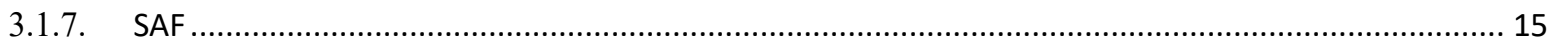

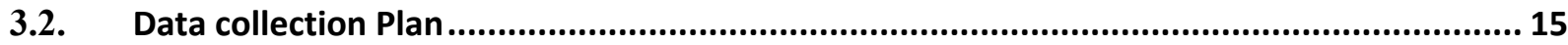

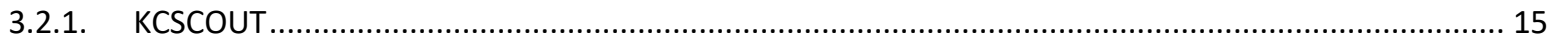

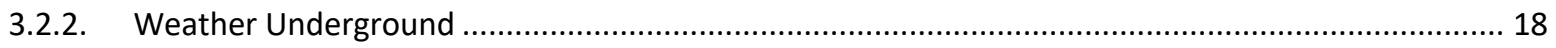

3.3. Capacity and Speed Adjustment Factors .............................................................................. 18

3.3.1. Estimation of Capacity Adjustment Factors (CAF) ...................................................................... 18

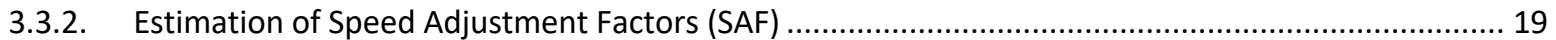

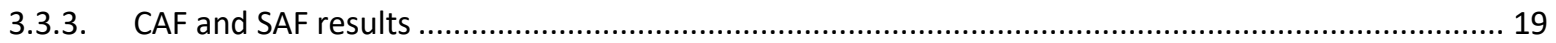

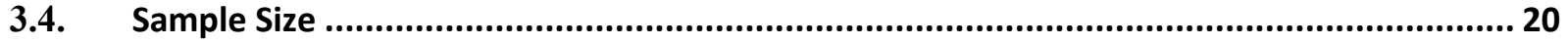

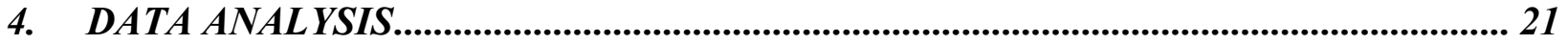

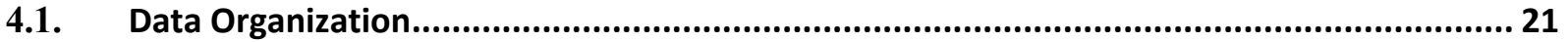

4.1.1. Incident with sensor upstream of lane closure ......................................................................... 22

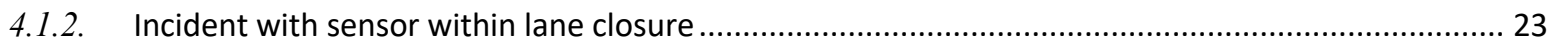

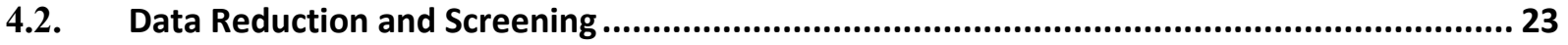

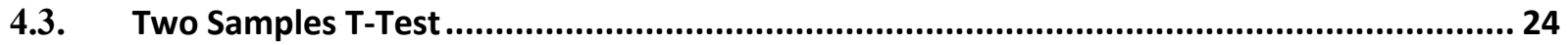

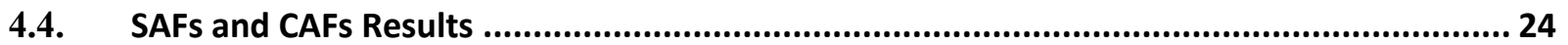

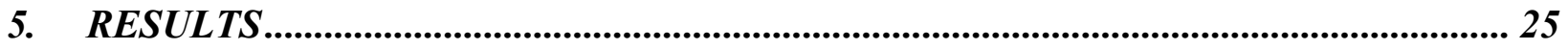

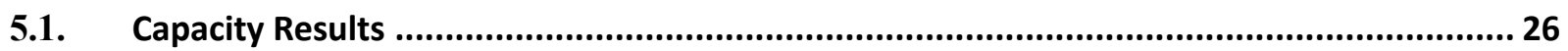

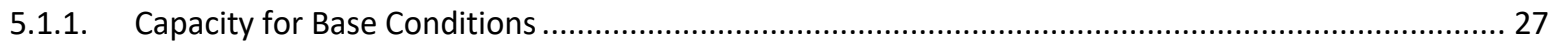

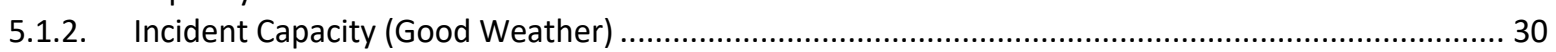

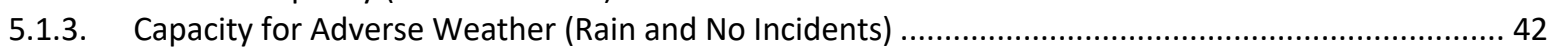

5.1.4. Capacity for Adverse Weather (Rain) and Incidents ..................................................................... 46 


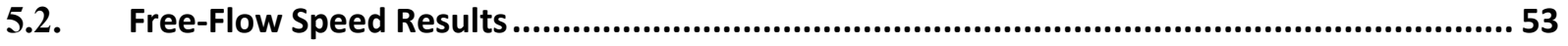

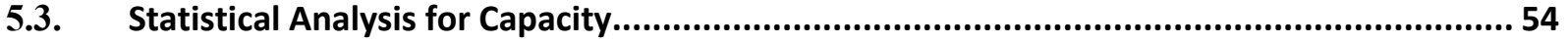

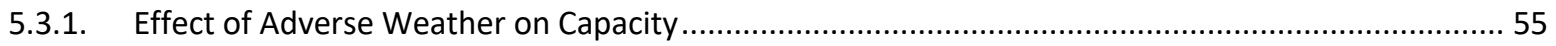

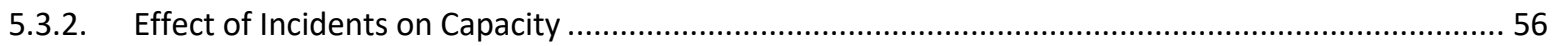

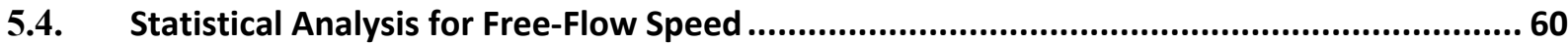

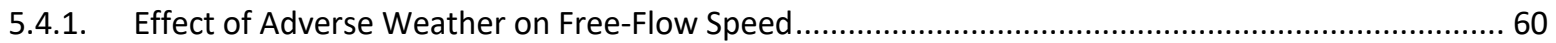

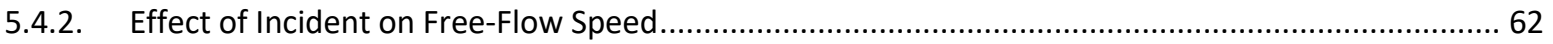

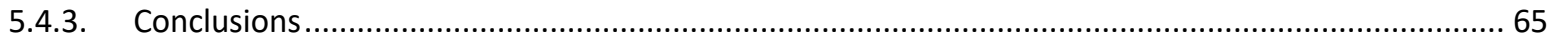

5.5. Capacity and Free-Flow Speed Adjustment Factors ...........................................................66

5.5.1. Capacity Adjustment Factors (CAF) for Adverse Weather (Rain) .................................................... 66

5.5.2. Capacity Adjustment Factors (CAF) for Incidents and Incidents with Rain ........................................6 66

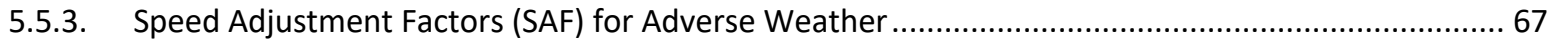

5.5.4. Speed Adjustment Factors (SAF) for Incidents and Incidents with Rain .......................................... 67

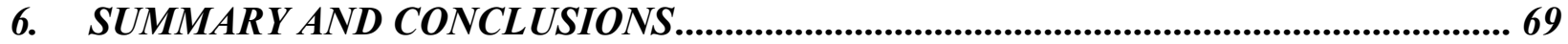

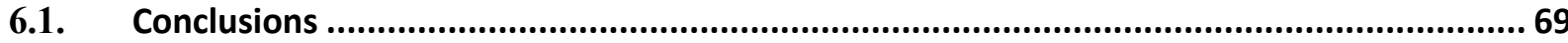

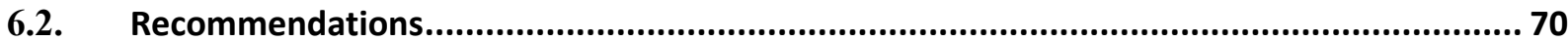

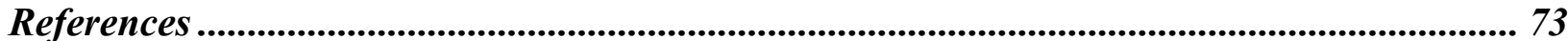




\section{List of Figures}

Figure 1 Weather Adjustment Factors as a Function of Rain Intensity, Rakha et al. (7).............. 6

Figure 2 Road capacity reductions for three rainfall conditions. (9) ......................................... 10

Figure 3 Percent drop in traffic parameters at various cities. Retrieved from Singh. (10)........... 11

Figure 4 Detector Stations Map (retrieved from http://www.kcscout.com/KcDataPortal) ........... 17

Figure 5 The exact location of the event, Google Maps ............................................................ 17

Figure 6 The target detector, upstream from the event (retrieved from

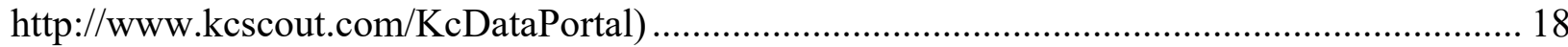

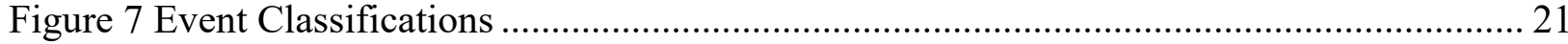

Figure 8 The hierarchy of the selected facility type for incident condition................................ 22

Figure 9 Incident with Sensor Upstream of a Lane Closure........................................................ 22

Figure 10 Incident with Sensor within Lane Closure ………….................................................. 23

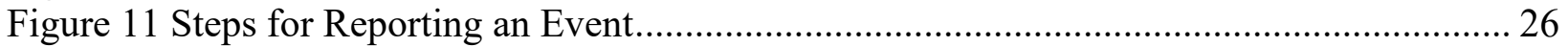

\section{List of Tables}

Table 1 Freeway Capacity Reductions under Incident Conditions (3) .......................................... 3

Table 2 Capacity Adjustment Factors (CAF) as function of Incidents (1) .................................... 4

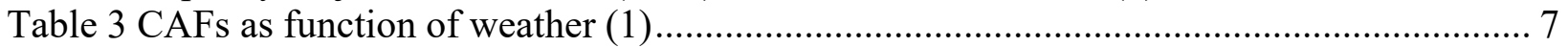

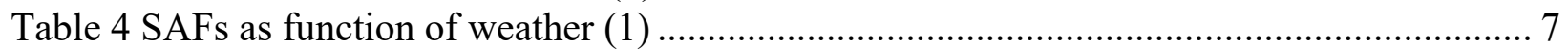

Table 5 Example from the Event Viewer report (retrieved from www.kcscout.com) .................. 16

Table 6 Base Conditions Capacity for Two-Lane Segments (Good Weather No Incidents) ........ 27

Table 7 Base Conditions Capacity for Three-Lane Segments (Good Weather No Incidents) ..... 28

Table 9 Incident Capacity for Two-Lanes Measured Upstream of Closures (Good Weather) .... 31

Table 10 Incident Capacity for Two-Lanes Measured within Closures (Good Weather) ............. 32

Table 11 Two-Lanes T-Statistic Between Incidents without Lane Closure and with One Lane

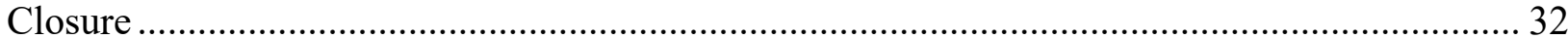

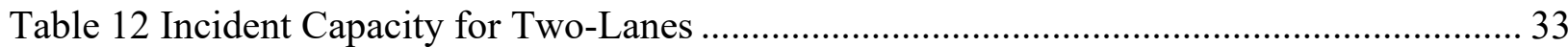

Table 13 Incident Capacity for Three-Lanes Measured Upstream of Closure (Good Weather) .. 34

Table 14 Incident Capacity for Three-Lane Measured Within Lane Closure (Good Weather and

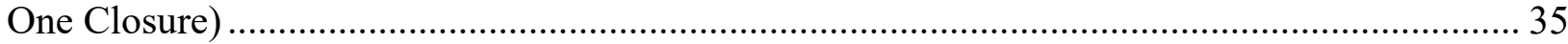

Table 15 Three-Lanes T-Statistic Between Incidents Measured Upstream and Within Lane

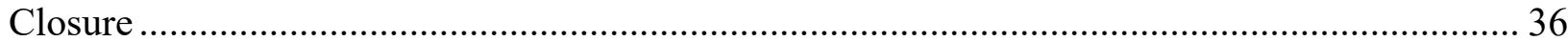

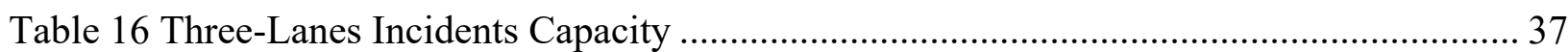

Table 17 Incident Capacity for Four-Lanes Measured Upstream of Closures (Good Weather) .. 38

Table 18 Incident Capacity for Four-Lane with One Lane Closures (Good Weather).................. 39

Table 19 Four-Lanes T-Statistic Between Incidents Measured Upstream and Within Lane

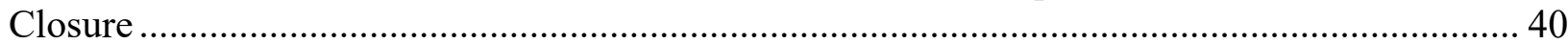

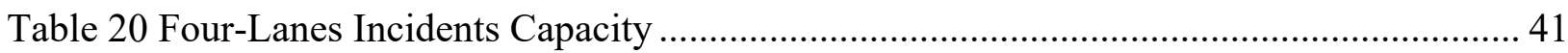

Table 21 Two-Lane Capacity During Adverse Weather (Rain) and no Incidents......................... 43

Table 22 Three-Lane Capacity During Adverse Weather (Rain) and no Incidents....................... 44

Table 23 Four-Lane Capacity During Adverse Weather (Rain) and no Incidents ......................... 45

Table 24 Rain and Incidents Capacity for Two-Lane (Measured Upstream of Closure) .............. 46 
Table 25 Rain and Incidents Capacity for Two-Lane (One Lane Closure).

Table 26 Two-Lanes T-Statistic Between Incidents during Rain Measured Upstream and Within

the Lane Closure 47

Table 27 Rain and Incidents Capacity for Three-Lane (Upstream of Closure) ......................... 48

Table 28 Rain and Incidents Capacity for Three-Lane (Within Closure).................................. 49

Table 29 Three-Lanes T-Statistic Between Incidents during Rain Upstream and Within Lane

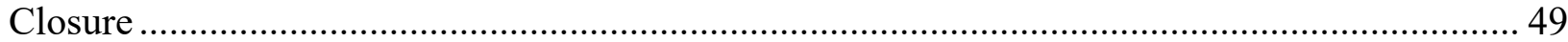

Table 30 Rain and Incidents Capacity for Four-Lane (Upstream of Closure)........................... 50

Table 31 Rain and Incidents Capacity for Four-Lane (Within Closure) .................................. 51

Table 32 Four-Lanes T-Statistic Between Incidents during Rain Measured Upstream and Within

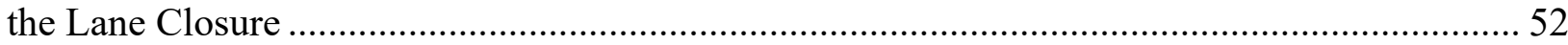

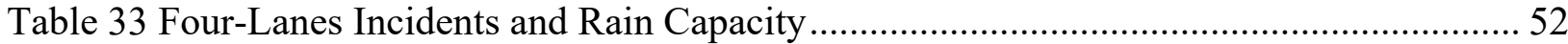

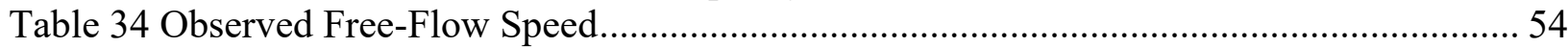

Table 35 T-Statistic for Two-Lane During Non-Incidents Conditions..................................... 55

Table 36 T-Statistic for Three-Lane During Non-Incidents Conditions.................................. 56

Table 37 T-Statistic for Four-Lane During Non-Incidents Conditions ................................... 56

Table 38 T-Statistic for Two-Lane Incidents Capacity...................................................... 57

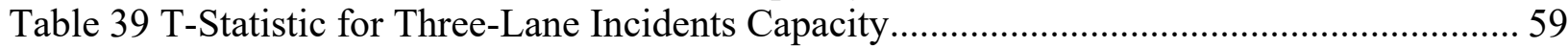

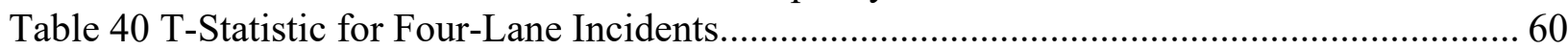

Table 41 T-Statistic for Two-Lane During Adverse Weather (Rain) ..................................... 61

Table 42 T-Statistic for Three-Lane During Adverse Weather (Rain) ...................................... 61

Table 43 T-Statistic for Four-Lane During Adverse Weather (Rain) ....................................... 62

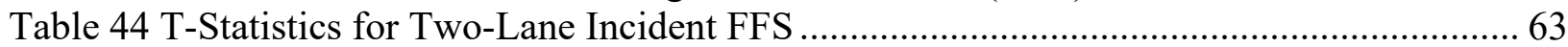

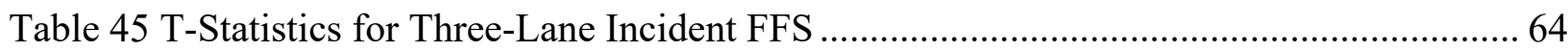

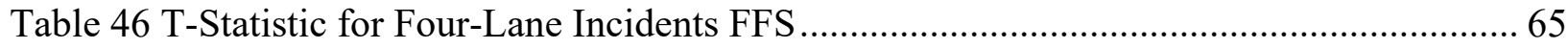

Table 47 Capacity Adjustment Factors (CAF) for Incidents and Incidents with Rain by Number

of Lanes 67

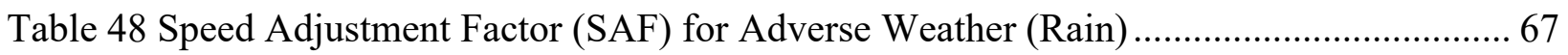

Table 49 Speed Adjustment Factors (SAF) for Incidents and Incidents with Rain.................... 68 


\section{INTRODUCTION}

\subsection{Problem Statement}

The Highway Capacity Manual, $6^{\text {th }}$ edition (HCM6) estimates a variety of adjustment factors as a function of incidents and adverse weather conditions (1). Capacity Adjustment Factors (CAF), and Speed Adjustment Factors (SAF) can be implemented for a facility to identify the remaining capacity or the free flow speed reduction during an incident or unfavorable weather condition. HCM6 assumes that incidents and adverse weather have an additive effect on capacity; however, this has not been validated through actual data. Also, the manual does not provide SAFs for incidents. As such, this thesis assessed the impact of incidents and adverse weather (rain) on capacity and free flow speed, by analyzing data from multiple freeways in Kansas City, and then compared them to the adjustment factors available in the HCM6 (chapter 11).

\subsection{Objective}

The objective of this thesis was to estimate the effect of rain and incidents on urbanized freeways' capacity and free flow speed and develop adjustment factors. This thesis also aimed at comparing the developed adjustment factors with those presented in the HCM6. 


\section{LITERATURE REVIEW}

The literature for this study was limited due to the novelty of this research, yet this chapter presents a brief literature review and recent findings related to this thesis topic. First, critical parameters that affect freeway capacity are described. After that, a summary of research on the impact of rainfall on roadway capacity and free-flow speed is presented.

\subsection{Effect of Incidents on Capacity and FFS}

While conceding the "Maximum Hourly Rate" as the capacity, Smith et al. (3) performed on analysis on demonstrating freeway capacity reduction caused by incidents. The effect of lane blockage on freeways with three lanes was considered for the study. Also, Smith et al. (3) estimated accident capacity as the minimum 10-minutes flow rate recorded in the bottleneck location caused by an incident. It was found that incidents dramatically reduced the remaining capacity on the sturdy locations. A $37 \%$ mean capacity was remaining when an incident blocked one out of three freeway lanes. Likewise, an incident with two closure out of three freeway lanes reduced the mean capacity by $77 \%$.

Chin et al. (4) studied the reduction of capacity due to temporary events such as crashes or weather. The study focused on all urban and rural freeways in the nation's highway system. The total number of open lanes and the number of lanes affected can identify the capacity reductions caused by incidents. Table (1) shows reduced capacity due to freeways incidents. For instance, an incident resulting in the closure of one lane on two-lanes freeways segment reduced the total capacity by $32 \%$. 
Table 1 Freeway Capacity Reductions under Incident Conditions (3)

\begin{tabular}{|c|c|c|c|c|}
\cline { 2 - 5 } \multicolumn{1}{c|}{} & \multicolumn{4}{c|}{ Lanes Blocked } \\
\hline $\begin{array}{c}\text { Number of } \\
\text { Lanes }\end{array}$ & Shoulder & 1-Lane & 2-Lanes & 3-Lanes \\
\hline 2 & 0.75 & 0.32 & 0.00 & N/A \\
\hline 3 & 0.84 & 0.53 & 0.22 & 0.00 \\
\hline 4 & 0.89 & 0.56 & 0.34 & $0.15^{*}$ \\
\hline 5 & $0.93 *$ & 0.75 & 0.50 & $0.20^{*}$ \\
\hline
\end{tabular}

*Assumed

Lu and Elefteriadou (5) estimated the capacity of freeways before and during incident events, and developed a model to evaluate capacity reduction due to incidents. They analyzed data obtained from five locations across North America. Traffic data that include freeway volumes, lane occupancy, and speed, were obtained from the Departments of Transportation (DOTs) archive, in 20- or 30-second intervals. The National Weather Service was used to collect weather records. Finally, incident data were acquired from the states' Highway Patrol agencies or the DOTs. To estimate the capacity, Lu and Elefteriadou defined the breakdown as the speed drops of $10 \mathrm{mi} / \mathrm{h}$ for at least 15 minutes.

Four capacity parameters were used in their research, specifically, breakdown flow, maximum pre-breakdown flow, average flow-rate for 10-minutes before breakdown, and average discharge flow. They estimated the available capacity after the incident and compare it with the HCM values. They also developed a regression model for total capacity reduction as a function of the time of incident and the type of lane closure (5).

The impact of incident on capacity and FFS was also evaluated by Kondyli et al. (6) on freeways with narrow lanes. Their analysis indicated that the FFS drop was not statistically significant. On the other hand, Kondyli et al. (6) observed a 22\% drop in capacity of in case of an incident or 
adverse weather, which was found to be statistically significant on twelve out of fourteen sites with the narrow lane segments.

HCM6 (1) provides default CAF values as a function of incidents. Table 2 shows the remaining capacity per open lane related to incident severity. For example, a six-lane directional facility might lose $25 \%$ of its original capacity when a two-lane closure scenario occurs, thus, the segment can handle only $75 \%$ of the available four open lanes' capacities. However, no information related to SAFs during incident conditions was found in the HCM6.

Table 2 Capacity Adjustment Factors (CAF) as function of Incidents (1)

\begin{tabular}{|l|l|l|l|l|l|l|}
\hline $\begin{array}{l}\text { Directional } \\
\text { lanes }\end{array}$ & $\begin{array}{l}\text { No } \\
\text { Incident }\end{array}$ & $\begin{array}{l}\text { Shoulder } \\
\text { Closed }\end{array}$ & $\begin{array}{l}\text { 1 Lane } \\
\text { Closed }\end{array}$ & $\begin{array}{l}\text { 2 Lane } \\
\text { Closed }\end{array}$ & $\begin{array}{l}\text { 3 Lane } \\
\text { Closed }\end{array}$ & $\begin{array}{l}\text { 4 Lane } \\
\text { Closed }\end{array}$ \\
\hline 2 & 1.00 & 0.81 & 0.70 & N/A & N/A & N/A \\
\hline 3 & 1.00 & 0.83 & 0.74 & 0.51 & N/A & N/A \\
\hline 4 & 1.00 & 0.85 & 0.77 & 0.50 & 0.52 & N/A \\
\hline 5 & 1.00 & 0.87 & 0.81 & 0.67 & 0.50 & 0.50 \\
\hline$\underline{6}$ & 1.00 & 0.89 & 0.85 & $\underline{0.75}$ & 0.52 & 0.52 \\
\hline 7 & 1.00 & 0.91 & 0.88 & 0.80 & 0.63 & 0.63 \\
\hline 8 & 1.00 & 0.93 & 0.89 & 0.84 & 0.66 & 0.66 \\
\hline
\end{tabular}

\subsection{Effect of Weather on Capacity and FFS}

Rakha et al. (7) conducted a study to quantify the effect of inclement weather on the behavior of the traffic stream. Traffic data including free-flow speed, speed at capacity, and jam density, as well as the weather data including precipitation and visibility, were observed in their study. Rakha et al. established adjustment factors for the following parameters: free-flow speed, speed at capacity, and capacity. The base condition was considered to be the no-precipitation condition with visibility of more than or equal to 3 miles. Data were collected at three major cities in the United States: Twin Cities, Minnesota; Seattle, Washington; and Baltimore, Maryland.

Moreover, data were obtained using loop detectors and microwave radar detectors for two years (2002-2004). The weather data were obtained from the Road Weather Information System 
(RWIS), and stations located at airports and operated by the National Weather Service. The analysis indicated that the weather conditions had no discernible impact on the traffic jam density. However, FFS, speed at capacity, and Capacity were reduced when light rain (intensity of $0.004 \mathrm{in} / \mathrm{hr}$ ) occurred for the ranges from $2 \%$ to $3.6 \%, 8 \%$ to $10 \%$, and $10 \%$ to $11 \%$, respectively. Generally, the increase in the rain amount would increase the reduction in FFS and speed at capacity. The study recorded a maximum decrease of FFS and speed at capacity as $6 \%$ to $9 \%$, and $8 \%$ to $14 \%$, respectively, depending on the rain intensity. Furthermore, the authors found that the roadway capacity remained steady and the reductions were approximately $10 \%$ to $11 \%$, depending on rain intensity range of 0 to $0.67 \mathrm{in} / \mathrm{hr}$. 
In contrast to FFS and speed at capacity, increased rain intensity between 0 and $0.67 \mathrm{in} / \mathrm{hr}$ did not affect the roadway capacity. Finally, the authors developed multiple adjustment factors as a function of rain intensity (Figure 1). As it can be seen in Figure 1, capacity differences between the weather adjustment factors in the three cities were not statistically significant. However, the differences between the free-flow speed and speed at capacity weather adjustment factors in the three cities were found to be statistically significant (7).
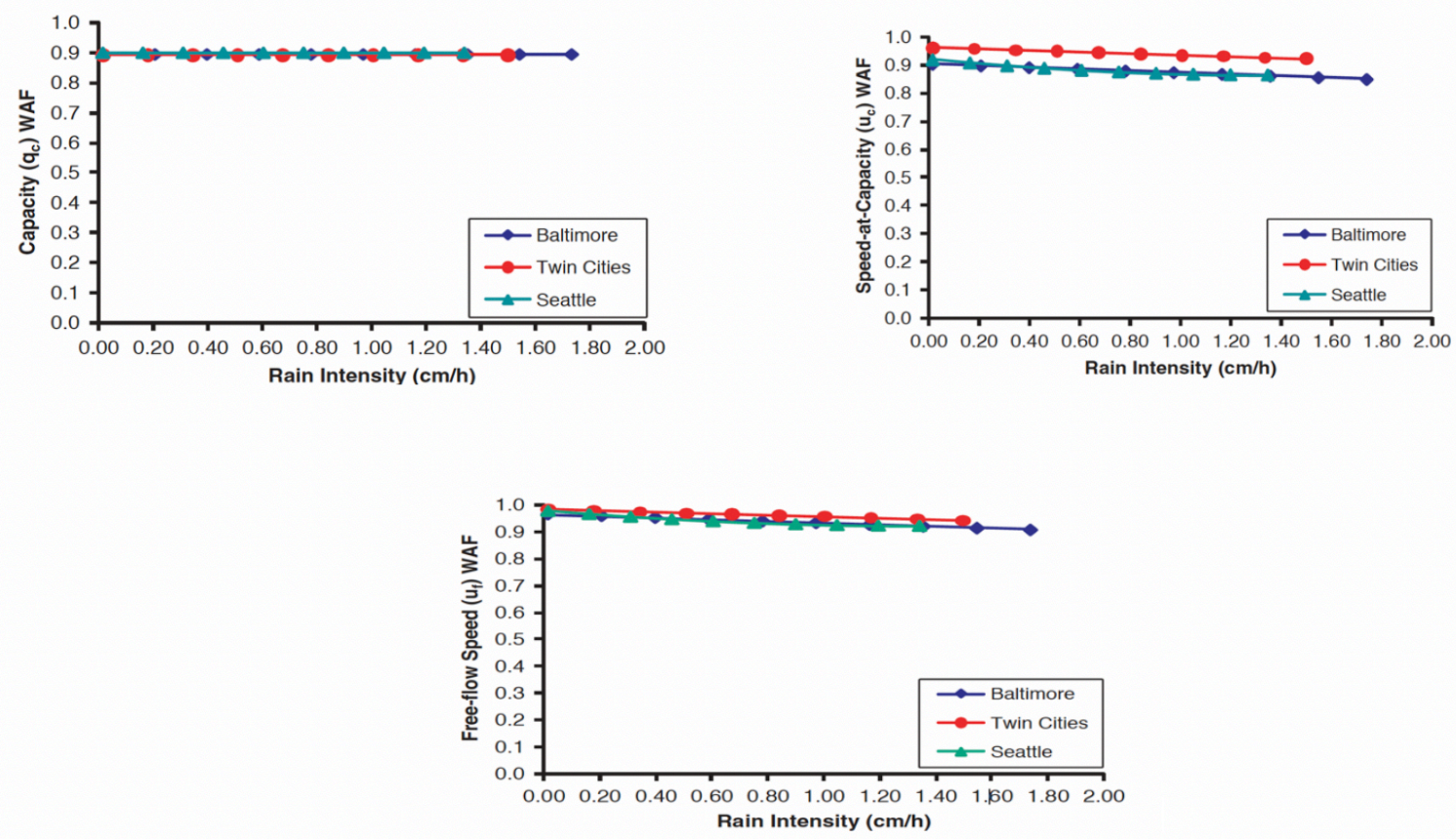

Figure 1 Weather Adjustment Factors as a Function of Rain Intensity, Rakha et al. (7).

The HCM6 provides default CAFs and SAFs as a function of weather type. Table 3 and Table 4 show CAFs and SAFs for medium and heavy rain, and the speed values in the table represent facility FFS. For example, a segment can maintain $92 \%$ of the actual capacity when medium rain occurs. Also, as shown in Table 3, a given FFS (e.g., 65mi/h) might drop by a certain percentage 
(e.g., 6\%) during medium rain condition. In addition, CAFs, as well as SAFs, are applied to the base capacity and FFS, respectively (1).

Table 3 CAFs as function of weather (1)

\begin{tabular}{|c|c|c|c|c|c|c|}
\hline \multirow[b]{2}{*}{ Weather Type } & \multirow[b]{2}{*}{ Intensity range } & \multicolumn{5}{|c|}{ Capacity Adjustment Factors (CAF) } \\
\hline & & $55 \mathrm{mi} / \mathrm{h}$ & $60 \mathrm{mi} / \mathrm{h}$ & $65 \mathrm{mi} / \mathrm{h}$ & $70 \mathrm{mi} / \mathrm{h}$ & $75 \mathrm{mi} / \mathrm{h}$ \\
\hline Medium Rain & $>0.1-0.25 \mathrm{in} / \mathrm{h}$ & 0.94 & 0.93 & 0.92 & 0.91 & 0.90 \\
\hline Heavy Rain & $>0.25 \mathrm{in} / \mathrm{h}$ & 0.89 & 0.88 & 0.86 & 0.84 & 0.82 \\
\hline Light snow & $>0.00-0.05 \mathrm{in} / \mathrm{h}$ & 0.97 & 0.96 & 0.96 & 0.95 & 0.95 \\
\hline Light-medium snow & $>0.05-0.10 \mathrm{in} / \mathrm{h}$ & 0.95 & 0.94 & 0.92 & 0.90 & 0.88 \\
\hline Medium-heavy snow & $>0.10-0.50 \mathrm{in} / \mathrm{h}$ & 0.93 & 0.91 & 0.90 & 0.88 & 0.87 \\
\hline Heavy snow & $>0.50 \mathrm{in} / \mathrm{h}$ & 0.80 & 0.78 & 0.76 & 0.74 & 0.72 \\
\hline Severe cold & $<-4^{\circ} \mathrm{F}$ & 0.93 & 0.92 & 0.92 & 0.91 & 0.90 \\
\hline Low visibility & $0.50-0.99 \mathrm{mi}$ & 0.90 & 0.90 & 0.90 & 0.90 & 0.90 \\
\hline Very low visibility & $0.25-0.49 \mathrm{mi}$ & 0.88 & 0.88 & 0.88 & 0.88 & 0.88 \\
\hline Minimal visibility & $<0.25 \mathrm{mi}$ & 0.90 & 0.90 & 0.90 & 0.90 & 0.90 \\
\hline Non-severe weather & $\begin{array}{l}\text { All conditions } \\
\text { not listed above }\end{array}$ & 1.00 & 1.00 & 1.00 & 1.00 & 1.00 \\
\hline
\end{tabular}

Table 4 SAFs as function of weather (1)

\begin{tabular}{|c|c|c|c|c|c|c|}
\hline \multirow[b]{2}{*}{ Weather Type } & \multirow[b]{2}{*}{ Intensity range } & \multicolumn{5}{|c|}{ Speed Adjustment Factors (SAF) } \\
\hline & & $55 \mathrm{mi} / \mathrm{h}$ & $60 \mathrm{mi} / \mathrm{h}$ & $65 \mathrm{mi} / \mathrm{h}$ & $70 \mathrm{mi} / \mathrm{h}$ & $75 \mathrm{mi} / \mathrm{h}$ \\
\hline Medium Rain & $>0.1-0.25 \mathrm{in} / \mathrm{h}$ & 0.96 & 0.95 & 0.94 & 0.93 & 0.93 \\
\hline Heavy Rain & $>0.25 \mathrm{in} / \mathrm{h}$ & 0.94 & 0.93 & 0.93 & 0.92 & 0.91 \\
\hline Light snow & $>0.00-0.05 \mathrm{in} / \mathrm{h}$ & 0.94 & 0.92 & 0.89 & 0.87 & 0.84 \\
\hline Light-medium snow & $>0.05-0.10 \mathrm{in} / \mathrm{h}$ & 0.92 & 0.90 & 0.88 & 0.86 & 0.83 \\
\hline Medium-heavy snow & $>0.10-0.50 \mathrm{in} / \mathrm{h}$ & 0.90 & 0.88 & 0.86 & 0.84 & 0.82 \\
\hline Heavy snow & $>0.50 \mathrm{in} / \mathrm{h}$ & 0.88 & 0.86 & 0.85 & 0.83 & 0.81 \\
\hline Severe cold & $<-4^{\circ} \mathrm{F}$ & 0.95 & 0.95 & 0.94 & 0.93 & 0.92 \\
\hline Low visibility & $0.50-0.99 \mathrm{mi}$ & 0.96 & 0.95 & 0.94 & 0.94 & 0.93 \\
\hline Very low visibility & $0.25-0.49 \mathrm{mi}$ & 0.95 & 0.94 & 0.93 & 0.92 & 0.91 \\
\hline Minimal visibility & $<0.25 \mathrm{mi}$ & 0.95 & 0.94 & 0.93 & 0.92 & 0.91 \\
\hline Non-severe weather & $\begin{array}{l}\text { All conditions } \\
\text { not listed above }\end{array}$ & 1.00 & 1.00 & 1.00 & 1.00 & 1.00 \\
\hline
\end{tabular}

Camacho et al. (8) evaluated the effect of inclement weather on FFS by developing several nonlinear regression models. The reduction in the FFS caused by different weather conditions such as rain, snow, wind speed, and visibility loss was quantified. Fifteen sites from Northwestern 
freeways in Spain were chosen for the study, and all of them were two-lane directional facilities. Moreover, the fifteen two-lane freeways were affected by the Atlantic climate, and, thus, were considered as the most cloudy and wettest locations in Spain. The authors stated that the annual rain amount for the selected stations was between 31.5 inches and 59 inches per year, and the average summer temperature was between $48 \mathrm{~F}^{\circ}$ and $64 \mathrm{~F}^{\circ}$.

Furthermore, weather and traffic data were collected using different measurement stations for the period between January 2006 to November 2008. Taking into account the time interval, the authors used one hour for the traffic data, while the weather stations provided data for 15- minute intervals. However, to make the analysis between the traffic and the weather variables data accurate, they divided the traffic data into four similar 15-minute intervals. Also, the weather variables were split into the following four groups:

1- Normal conditions and temperature above $32 \mathrm{~F}^{\circ}$.

2- Normal conditions and temperature below $32 \mathrm{~F}^{\circ}$.

3- Rain.

4- Snow.

It was found that the rainfall had an impact on the FFS between $3.4 \mathrm{mi} / \mathrm{hr}$ to $4.3 \mathrm{mi} / \mathrm{hr}$ depending on the intensity. Furthermore, snow reduced the FFS dramatically from $5.6 \mathrm{mi} / \mathrm{hr}$ to $8.5 \mathrm{mi} / \mathrm{hr}$. As long as the wind speed was greater than $8 \mathrm{~m} / \mathrm{s}$, speed was affected. Likewise, no effect was observed on the FFS when the visibility was around 1.2 miles (8).

Jia et al. (9) quantified the effect of different rainfall intensity levels on urbanized facilities in China. Beijing was the main scope of the authors' study due to the abundance of traffic data that have been recorded for years. They collected data on three streets, which had a maximum speed of $50 \mathrm{mi} / \mathrm{hr}$, an average daily traffic of more than 100,000 vehicles, three lanes in each direction, 
and nearly 100 loop detectors spread over every kilometer on each lane. Moreover, the twominute interval traffic data included flow rates, mean speeds, and lane occupancies, and these were retrieved from the Beijing Traffic Management Bureau (BTMB).

Furthermore, the hourly rain data were obtained by the National Meteorological Center (NMC). It was found that as the level of the rainfall increased, the capacity of each facility chosen in the study (both directions) decreased (figure 2). The average reduction was found to be $5 \%$ to $10 \%$ for light rain, $13 \%$ to $21 \%$ for medium rain, and finally $17 \%$ to $25 \%$ for heavy rain. Statistically, the difference between the three rainfall categories was examined to determine whether the reductions among them were significant. Using the Bonferroni test with 0.05 significance level, it was discovered that the reductions are meaningful when compared to good weather conditions, whereas no such differences were found between medium and heavy rain as the data points from heavy rain category were insignificant (9). 


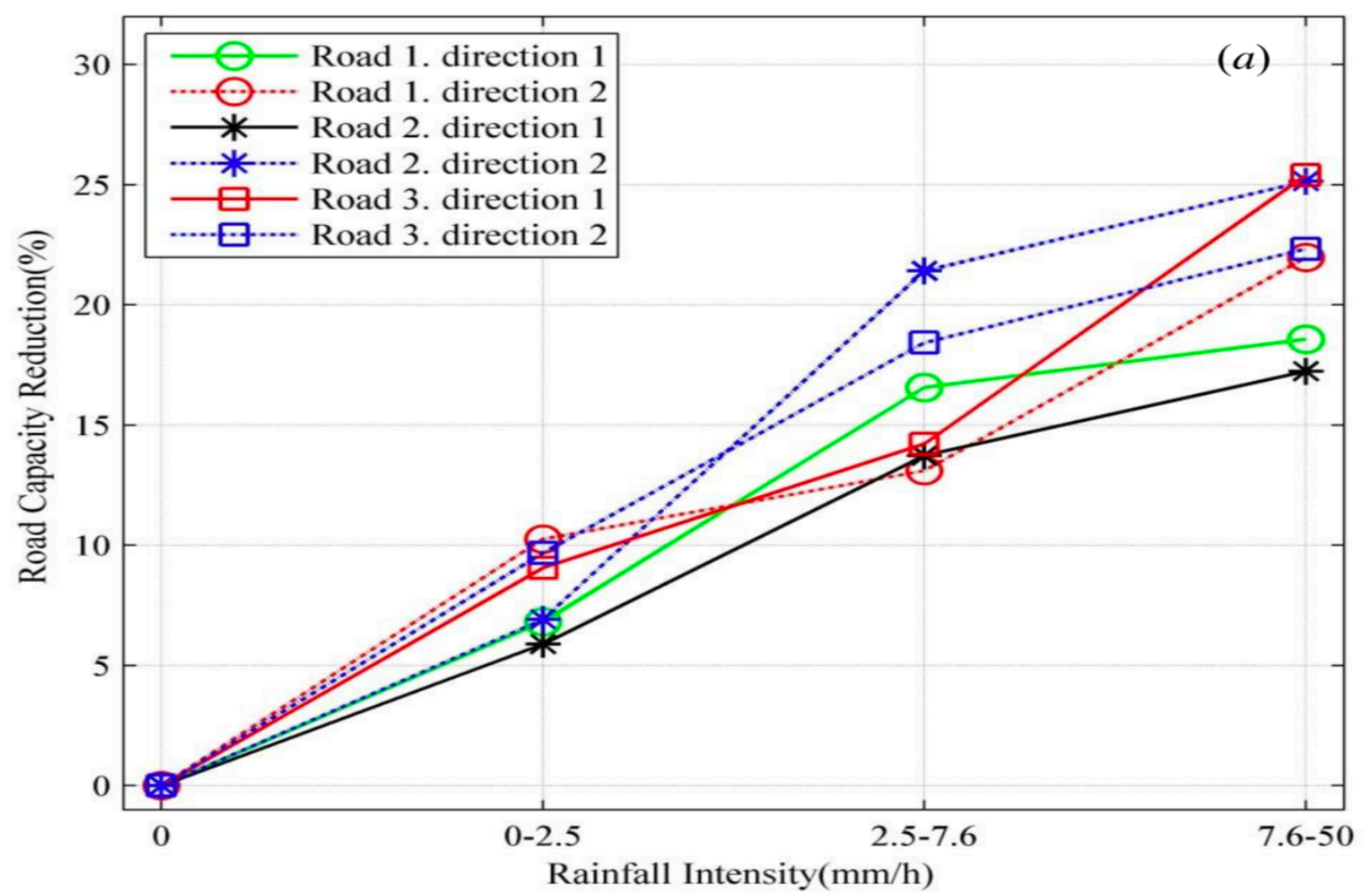

Figure 2 Road capacity reductions for three rainfall conditions. (9)

In 2017, Singh (10) evaluated the impact of rainfall on key traffic parameters, free-flow speed, speed at capacity, and capacity in dry places. The main objective was to examine the effect of rain on traffic parameters in dry locations, and compare it to previous investigations, which were focused more on the wet areas, and then to determine if there were any regional differences between them. Six freeways, I-10, I-5, I-210, I-405, and I-105, in Southern California, were chosen for the study. About 4,550 stations and 10,000 loop detectors provided by Caltrans Performance Measurement System (PeMS), in Los Angeles County collected the traffic data for the study. Also, the data included speed, flow, and lane occupancy that were downloaded in fiveminute intervals from 2009 to 2015.

Furthermore, 15-minute precipitation data were retrieved by the Los Angeles Hydrology Department. The author compared the reduction in traffic parameters due to rainfall with two 
other sources, HCM 2010 (2) and Rakha et al. (10). Figure 3 shows the percent drop in free-flow speed, speed at capacity, and capacity from Rakha et al. (7), HCM 2010, and Singh (10) in multiple cities.

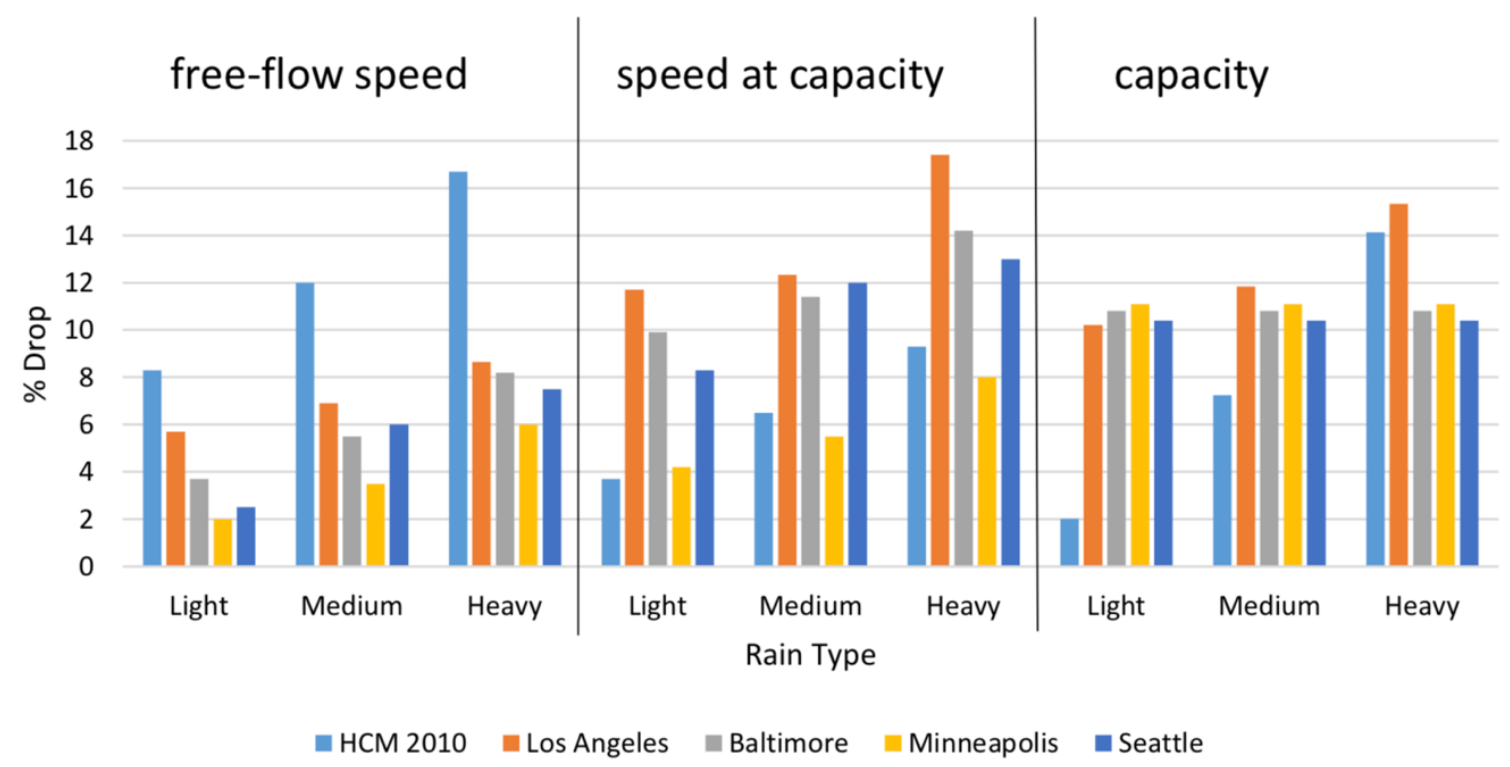

Figure 3 Percent drop in traffic parameters at various cities. Retrieved from Singh. (10).

Generally, the impact of rain on the free-flow speed, the speed at capacity, and the capacity of freeways, and the outcomes were found to be different from the previous recourses in the following ways:

1- Free-flow speed was reduced due to light, medium and heavy rain on an average of $5.7 \%, 6.91 \%$, and $8.65 \%$, respectively. However, these reductions are less compared to the HCM and Rakha et al. (7).

2- The average drops in the speed at capacity due to different rainfall amounts were found to be higher than HCM 2010 and Rakha et al (7) by $11.71 \%$ for light rain, $12.34 \%$ for medium rain, and $17.4 \%$ for heavy rain. 
3- The average capacity was also dropped for light, medium, and heavy rain, by $10.22 \%$, $11.85 \%$, and $17.4 \%$, respectively. These reductions in capacity were found to be more than the results from HCM 2010 (8) for the medium and heavy rain. Nevertheless, for the light rain, the reduction was greater compared to HCM 2010, and somewhat less than Rakha et al. (7). (10).

\subsection{Summary}

Capacity can be examined under four parameters, breakdown flow, maximum pre-breakdown flow, average flow-rate for 10-minutes before breakdown, and average discharge flow. According to Lu and Elefteriadou (5), the capacity under incident conditions can be estimated using two factors; the average discharge flow per open lane when both an incident and congestion are present, and the minimum 10-minute flow rates during that same period. Finally, in most cases, rain has an impact on capacity and FFS at different intensity levels. 


\section{METHODOLOGY}

This chapter provides an overview of the methodology used to complete the research. First, the definitions of traffic stream parameters that were utilized as part of the analysis are presented. Then, the data collection plan and general procedures are addressed. After that, data collection recourses and the expected data points are discussed.

\subsection{Key Traffic Stream Parameters}

Based on the literature, the definition of capacity can vary depending on the researcher. Also, the capacity measurement involves different traffic parameters. As a result, this section defined the essential key parameters that helped define capacity and FFS.

\subsubsection{Breakdown}

The definition of capacity is related to the breakdown event (11). When traffic demand is more than capacity, a sudden drop in speed occurs (i.e., breakdown) (1) (11). Based on the literature $((5),(11))$ the identification of a breakdown can be found as the sudden drop of speed by more than $10 \mathrm{mi} / \mathrm{h}$. However, in this research, breakdown was assumed to occur when speed drops below $75 \%$ of the FFS, according to the HCM definition (1). This method has been previously practiced by Asgharzadeh and Kondyli (13) and Kondyli et al. (6) and it was further improved by Asgharzadeh and Kondyli (14) by including the speed drop intensity (percentage) as a factor of breakdown.

\subsubsection{Free Flow Speed (FFS)}

Determining the Free-Flow Speed reduction is one of this thesis objectives. The FFS is also a tool used for capacity identification. Moreover, the Free-Flow Speed can be found at a point when the density is very low (12). In this research, FFS is defined as the average speed of a facility under low flow rate (12), i.e., less than $1,000 \mathrm{veh} / \mathrm{hr} / \mathrm{ln}$. 


\subsubsection{Pre-Breakdown Flow Rate}

This is defined as the average 5-minute flow rate right before the speed drops below $75 \%$ of the FFS (11).

\subsubsection{Average Discharge Flow}

This definition was obtained from Elefteriadou (11), and it is the average per lane flow rate after the breakdown event, measure during congested conditions with a duration of at least three 5minute intervals (15 minutes).

\subsubsection{Capacity and FFS Measurements}

Capacity definition varies depending on the prevailing conditions. Four types of prevailing conditions were considered in this study, and capacity under each condition is defined below. Also, in this thesis, capacity was not the maximum flow rate. Instead, pre-breakdown flow and discharge flow for non-incidents and incidents events, respectively, were used for capacity description. FFS measurement information is also provided below.

\section{Base Conditions (good weather, no incident)}

For this type of conditions, congestion occurs due to excess of demand, and not due to an incident. As such, capacity is defined as the pre-breakdown flow rate. FFS was measured at the same locations under low flow conditions.

\section{Incidents and Good Weather}

During incidents, the average discharge flow was used as the capacity. Average discharge flow was chosen instead of pre-breakdown flow because incidents were assumed to cause the congestion. In those cases where an incident occurred, but the incident was not significant enough to cause congestion, FFS was measured, if the flow was less than $1,000 \mathrm{veh} / \mathrm{hr} / \mathrm{ln}$. 


\section{Adverse Weather (rain) and No Incidents}

The average pre-breakdown flow rate was assumed to be the capacity, in case of a breakdown. Also, the average speed at the same location when the flow rate was lower than $1,000 \mathrm{veh} / \mathrm{hr} / \mathrm{ln}$ was the adverse weather FFS, in case on free-flowing conditions.

\section{Adverse Weather (rain) and Incidents}

The average discharge flow was assumed to be the capacity here. Additionally, FFS was defined as the average speed during an incident/adverse weather event that did not lead to congestion.

\subsubsection{CAF}

According to the HCM 2016, the capacity adjustment factor can be defined as the percent of the capacity remaining after a particular event occurred such as incident or adverse weather (1).

\subsubsection{SAF}

This is the average speed remaining during particular events such as incident or adverse weather (1).

\subsection{Data collection Plan}

This section describes the data collection recourses and methods used to obtain traffic, incident, and weather data. Also, this section provides an overview of the procedures used to collect and analyze the data.

Data including traffic and weather were collected for the period from 2014 to 2018 on various freeways in Kansas City. Two-lane, three-lane, and four-lane freeways, in each direction were considered in this study. Additionally, data were obtained using two major data portal websites: KCSCOUT and Weather Underground, WU.

\subsubsection{KCSCOUT}

Traffic data were collected through KCSCOUT (www.kcscout.com), Kansas City's bi-state traffic management system. KCSCOUT measures traffic in the Kansas City metropolitan area by 
using various loop detectors that spread over more than 300 miles of freeways. As part of this source's features, two portals from KCSCOUT were used to collect the traffic and incident data for the study. The two portals are described in the following section.

\section{Event Viewer}

Event viewer was the starting point of the research data to locate the historical incidents that took place in Kansas City. KCSCOUT reports any event such as crash or stalled vehicle. The inquiry from this web page can cover an event with numerous details. For example, a major or minor accident or stalled car is categorized as the event type. Also, the report allows the user to identify the location of the event, for example, I-435 WB and Antioch Rd.

Furthermore, the lane pattern can be classified as the following; ML: Middle lane LE: Lane exit/entrance, LS: Left shoulder. The example from Table 5 shows there was a minor accident on I-435 WB at Antioch Rd in July 2016. The segment where the accident occurred had initially three lanes in each direction, and one became blocked due to the incident. By using Google Maps, the longitude and latitude information provides the exact location of the event.

Table 5 Example from the Event Viewer report (retrieved from www.kcscout.com)

\begin{tabular}{|c|c|c|c|c|c|c|c|c|c|c|c|c|}
\hline Event Type & Road Type & Main Street & Cross Street & Direction & $\begin{array}{l}\text { Latitude } \\
\end{array}$ & Longitude & County & State & Start Time & Event Cleared & Lane Pattern ${ }^{*}$ & Blocked Lanes \\
\hline minor accident & & I-435 WB & AT ANTIOCH RD & W & 38.934426 & -94.682443 & 3 Johnson & KS & $72 / 166: 51$ & $7 / 2167: 35$ & 5 ML/ML/ML/ML & |LSIML| \\
\hline accident & E & I- $-35 \mathrm{SB}$ & TO 12TH ST & $\mathrm{S}_{\mathrm{s}}$ & 39.101881 & -94.594093 & 3 Jackson & M0 & $7 / 3 / 167: 08$ & $7 / 3 / 167: 37$ & | LEEMLRE| & |ML \\
\hline minor accident & & $\mathrm{I}-70 \mathrm{~EB}$ & PAST 3IST ST & E & 39.072714 & -94.531049 & 9) Jackson & M0 & $77 / 166: 13$ & $77 / 166: 51$ & $\mid$ LSIMLMLMLRS| & |LSMLML| \\
\hline iden & & $\mathrm{I}-70 \mathrm{~EB}$ & PAST FAIRFAX & & 39.107515 & -94.603604 & 4 Jackson & M0 & $7 / 121165: 50$ & $121166: 37$ & ILRERS & LSML \\
\hline
\end{tabular}

\section{TransSuite data portal}

The TransSuite web-based Data Portal included the detector stations map and it was used to choose the detectors to obtain the traffic data as shown in Figure 4. Google maps were also used to determine the exact location of the bottlenecks and identify the detectors to collect the data. The data collection focused on typical bottleneck locations, and data downstream of the 
bottleneck were obtained for the capacity measurements. If congestion took place because of queue spillback from a downstream bottleneck, the capacity data were not analyzed further (9). Figures 5 and 6 are illustrations of incidents retrieved from Table 4. The event happened at I-435 WB, and upstream of Antioch Rd, so the detector with the red circle is located upstream and close enough to the event location.

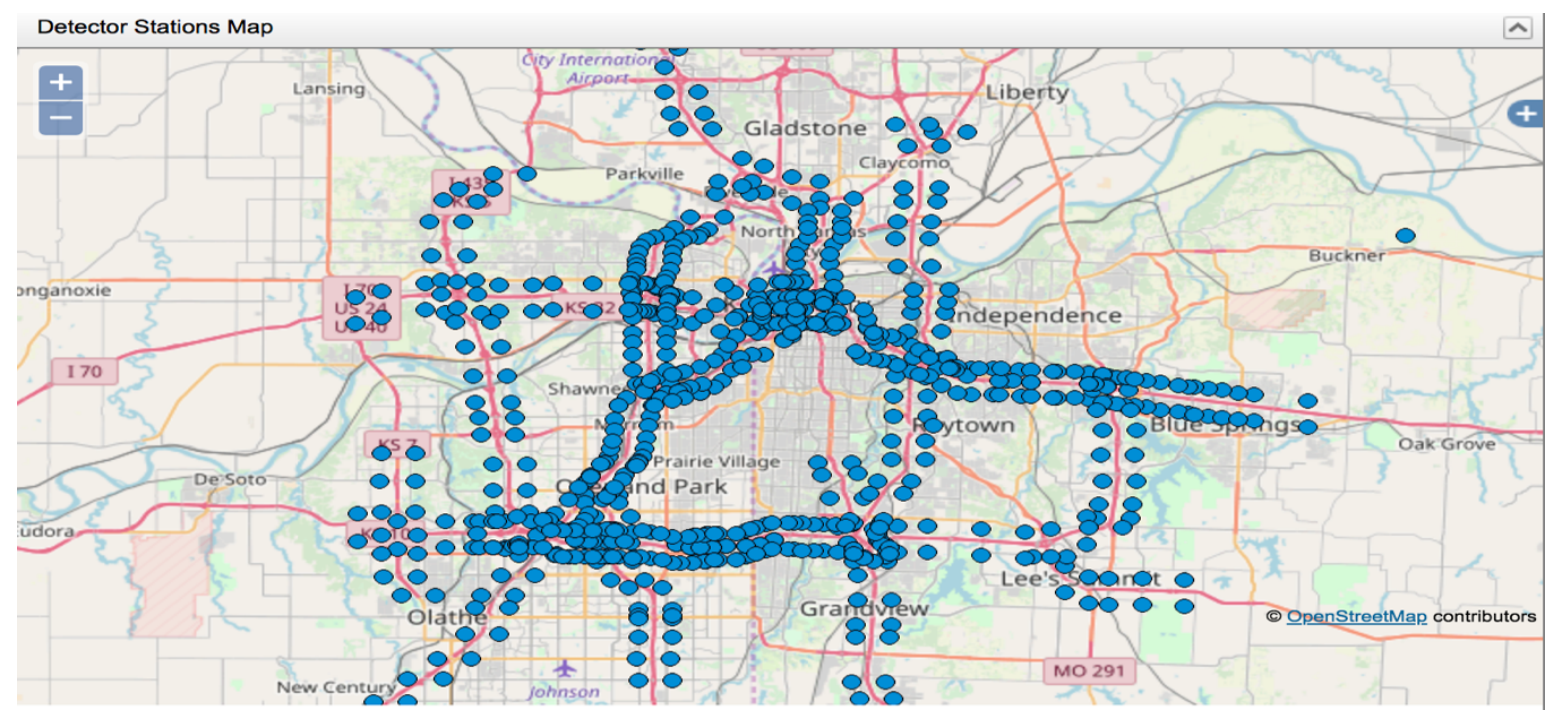

Figure 4 Detector Stations Map (retrieved from http://www.kcscout.com/KcDataPortal)

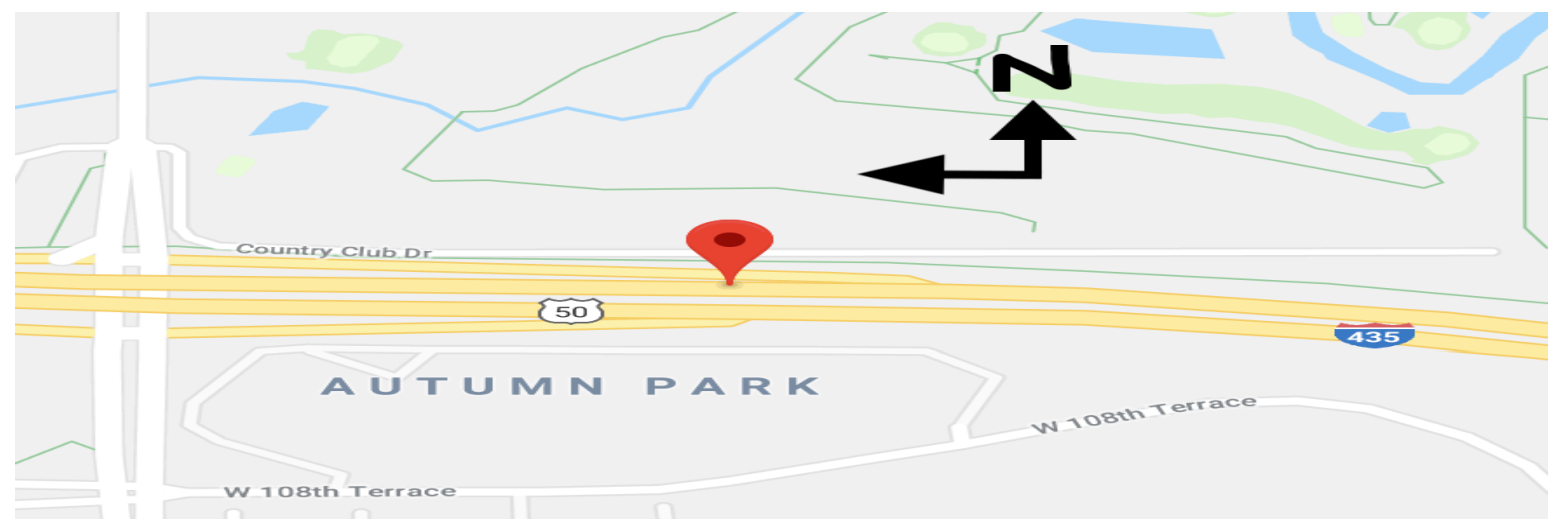

Figure 5 The exact location of the event, Google Maps 


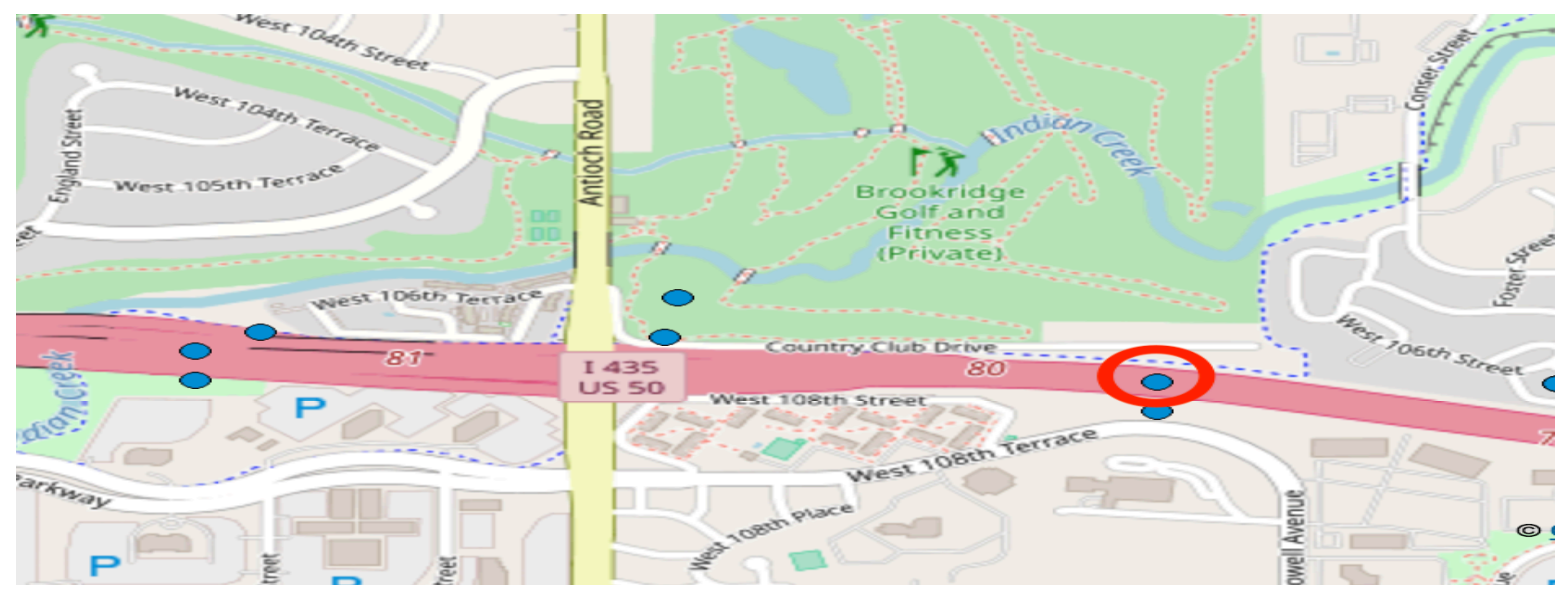

Figure 6 The target detector, upstream from the event (retrieved from

http://www.kcscout.com/KcDataPortal)

\subsubsection{Weather Underground}

Weather data were obtained using historical records from the Weather Underground website.

The Weather Underground website informs users about weather history of a particular area. Also, from this site, researchers can find hourly weather information during a specific day. Finally, only one weather category, "rain", was considered in the analysis, because snow events were not very frequent in the area.

\subsection{Capacity and Speed Adjustment Factors}

Following the HCM 2016 procedure, the effect of incidents and weather on capacity and FreeFlow Speed was converted as the default adjustment factors that affect the base conditions of a freeway segment. Those adjustment factors generally describe the remaining capacity for CAF, and the remaining FFS for the SAF. The final results include multiple adjustment factors, and were also compared with those from the HCM 2016.

\subsubsection{Estimation of Capacity Adjustment Factors (CAF)}

In order to estimate CAFs, the average breakdown and discharge flow were compared to the base conditions as follows: 


\section{- CAF for bad weather conditions (rain) and no incident}

CAF was estimated as the ratio of the average breakdown flow during rain to the average breakdown flow during the base conditions, as a function of number of lanes.

\section{- CAF for incidents (good weather)}

CAF for incident conditions was estimated as the ratio of the average discharge flow during incidents to the average discharge flow during base conditions, as a function of the number of lanes as well as the measurement location (within or upstream of the lane closure).

\section{CAF for rain and incident}

$\mathrm{CAF}$ for both rain and incidents conditions was estimated as the ratio of the average discharge flow during the event of incident with rain, to the average discharge flow from the base conditions.

\subsubsection{Estimation of Speed Adjustment Factors (SAF)}

The FFS for the different conditions, rain no incident, incident, and incident with rain, were compared to the base Free-Flow Speed during the base conditions (good weather, no incident). As it was discussed previously, under non-incident conditions, FFS was defined as the average speed when the flow rate is as low as $1,000 \mathrm{veh} / \mathrm{hr} / \mathrm{ln}$. Also, for incident conditions, FFS was measured as the average speed during the incident period, assuming that the incident did not result in a traffic breakdown.

\subsubsection{CAF and SAF results}

The HCM 2016 assumes that when we compare two independent events that influence the capacity and the FFS, for example, rain and incidents, their combined effect can be estimated by multiplying the individual CAFs or SAFs (1). On the other hand, the methodology of this thesis resulted in multiple CAFs and SAFs, including the factors that were produced from the two combined events (incidents and adverse weather) at the same time. Next, the resulting adjustment factors were compared to those from the HCM 2016. Finally, two-sample t-tests were used to investigate the statistical difference between the different event groups. 


\subsection{Sample Size}

The goal of the thesis was to collect data for two, three, and four lane directional freeways, considering also the measurement location, in case of incidents. As such, an effort was made to include at least 30 observations in each group. However, given the scattered and random occurrence of incidents, in some cases it was not possible to collect a large number of observations for each group, even if a large duration (4 years) was considered in this study. 


\section{DATA ANALYSIS}

This section summarizes the procedures that were applied to collected data.

\subsection{Data Organization}

Traffic data were first arranged as non-incident or incident conditions. Under each group, two sub-groups that included good weather or rain were generated (Figure 7). In addition, as shown in Figure 8, each sub-group was further divided based on the number of freeway lanes in each direction (two, three, or four lanes), as well as the incident type (upstream of closure, within closure).

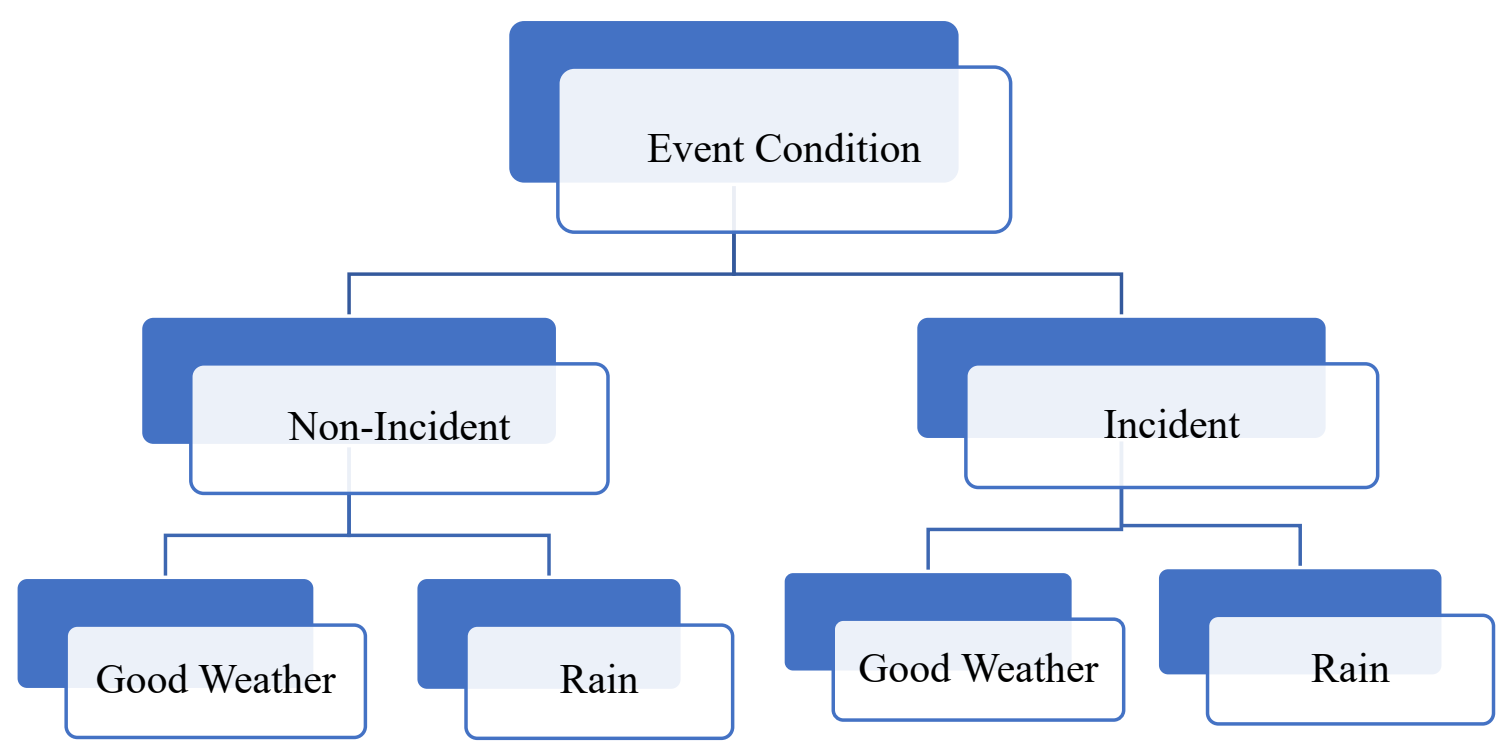

Figure 7 Event Classifications 


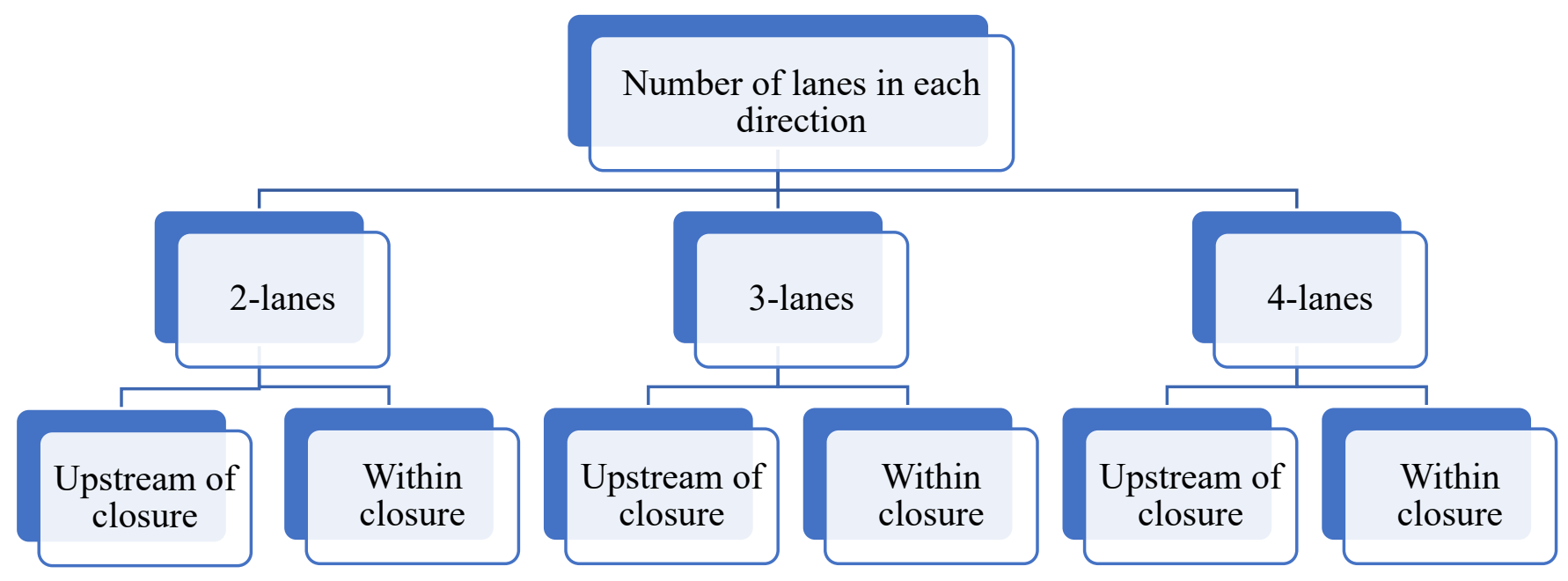

Figure 8 The hierarchy of the selected facility type for incident condition

\subsubsection{Incident with sensor upstream of lane closure}

This case included incident events where the nearest upstream sensor was located upstream of the lane closure (Figure 9). However, this did not mean that the sensor was far away from the incident location, since the breakdown time recorded in the sensor matched with the event time from the event report. Although this type of incidents is associated with lane closure from the event viewer report, the sensor is located further upstream from the closure, and it captures the queued vehicles at that location due to the incident event.

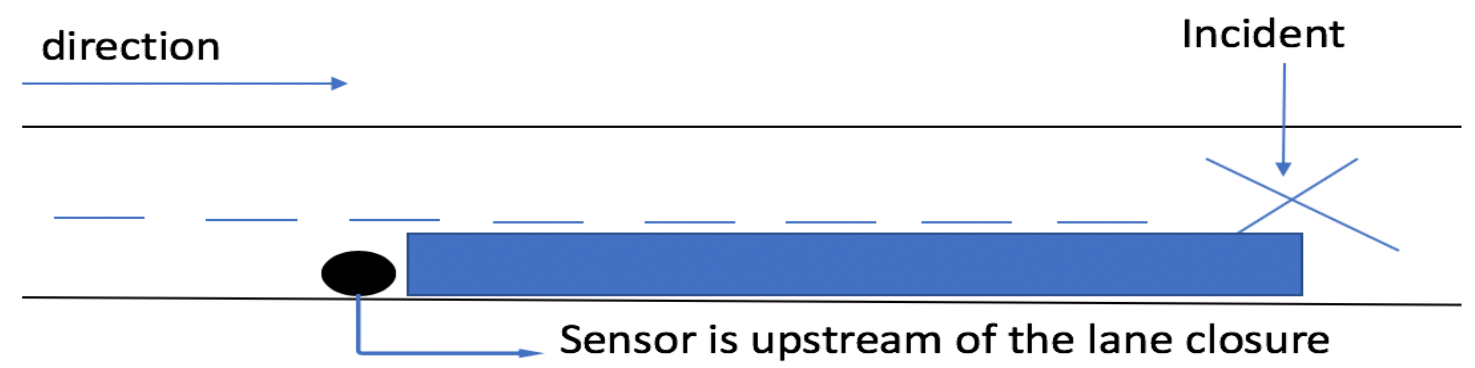

Figure 9 Incident with Sensor Upstream of a Lane Closure. 


\subsubsection{Incident with sensor within lane closure}

This case included incident events where the sensor was located upstream of the incident, but within the lane closure (Figure 10). In this case, the sensor data matched the event viewer information, in that the measurement point was within the lane closure. Similar to the previous situation, the breakdown times from the sensor matched those from the event record.

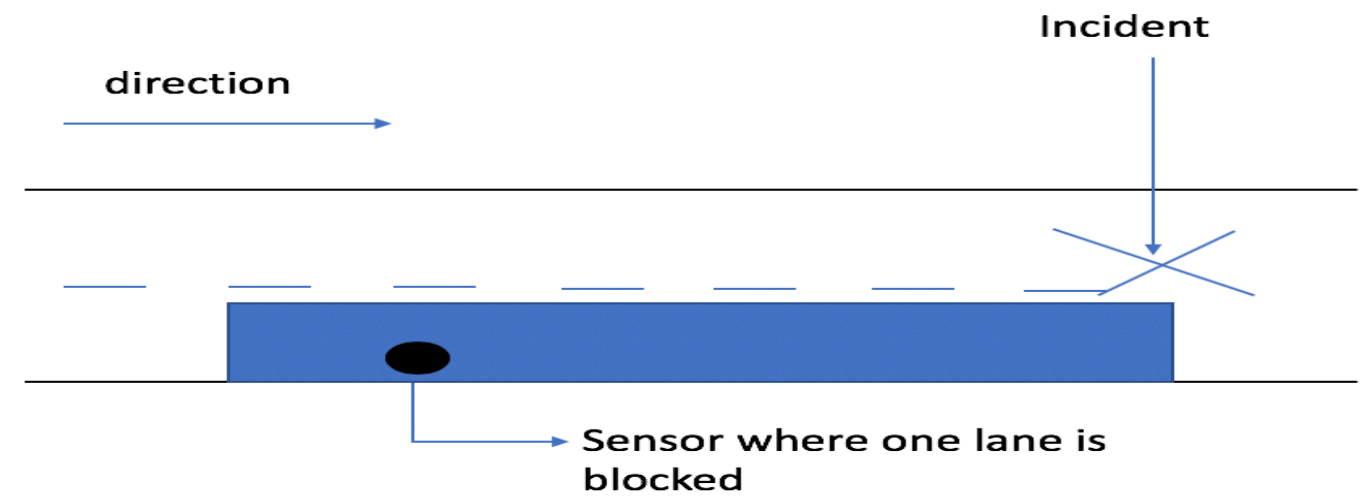

Figure 10 Incident with Sensor within Lane Closure

\subsection{Data Reduction and Screening}

Data were screened to ensure that they represent breakdown conditions during an event, as described earlier. If an inquiry from a detector did not match the timeline of the event from the event viewer report, it was excluded from the analysis. According to Elefteriadou (11), the congestion duration should be at least for 15 minutes (11). Breakdowns that occurred at an average flow rate of less than $1,300 \mathrm{veh} / \mathrm{hr} / \mathrm{ln}$ for non-incident scenarios, and the average discharge flow rate for incident events less than $900 \mathrm{veh} / \mathrm{hr} / \mathrm{ln}$, were also removed as these were considered as extremely low. Finally, the data quality is an important indicator of the detector performance, so data quality less than $80 \%$ as provided by KC SCOUT was not utilized for this thesis. 


\subsection{Two Samples T-Test}

T-tests were applied to determine whether the difference between the mean capacities found in the sample data is significantly different. The null hypothesis states that there is no difference between the two population means (e.g., capacity between base conditions and incidents), and the alternative hypotheses states that there is a difference. A 95\% confidence level was used.

$\mathrm{H}_{0}: \mu_{1}=\mu_{2}$

$\mathrm{H}_{\mathrm{a}}: \mu_{1} \neq \mu_{2}$

Where:

$\mu_{1}$ mean capacity for base conditions

$\mu_{2}$ : mean capacity for rain, incident, or rain and incident conditions

\subsection{SAFs and CAFs Results}

Tables for each category were developed:

- As a function of the number of lanes and measurement location (within or upstream of the lane closure), tables for CAFs and SAFs for incident conditions (incidents or incidents with rain). 


\section{RESULTS}

This chapter presents the results of the data analysis. Data were collected to find incident events for each category (e.g., rain with incident for three lanes) for each lane blockage. After that, the data from the same location were collected for the base scenario (i.e., congestion that was not caused by incidents and during good weather). Figure 11 shows how each event for the study was reported. Breakdown or discharge flow rates per lane and average across all lanes were reported in 5-minute intervals and converted to hourly volumes. Weather data were reported hourly.

Capacity Adjustment Factors (CAF) and Speed Adjustment Factors (SAF) were developed by comparing their averages during base conditions with their averages during rain, and for nonincident events. Also, similar adjustment factors were developed as a function of incidents by number of lanes by comparing the base conditions to incidents-only and incidents with rain. Thus, t-tests were performed between these conditions to investigate potential differences between the average capacities and speeds under base conditions, and the remaining conditions. Finally, tables for CAF and SAF are also presented. 


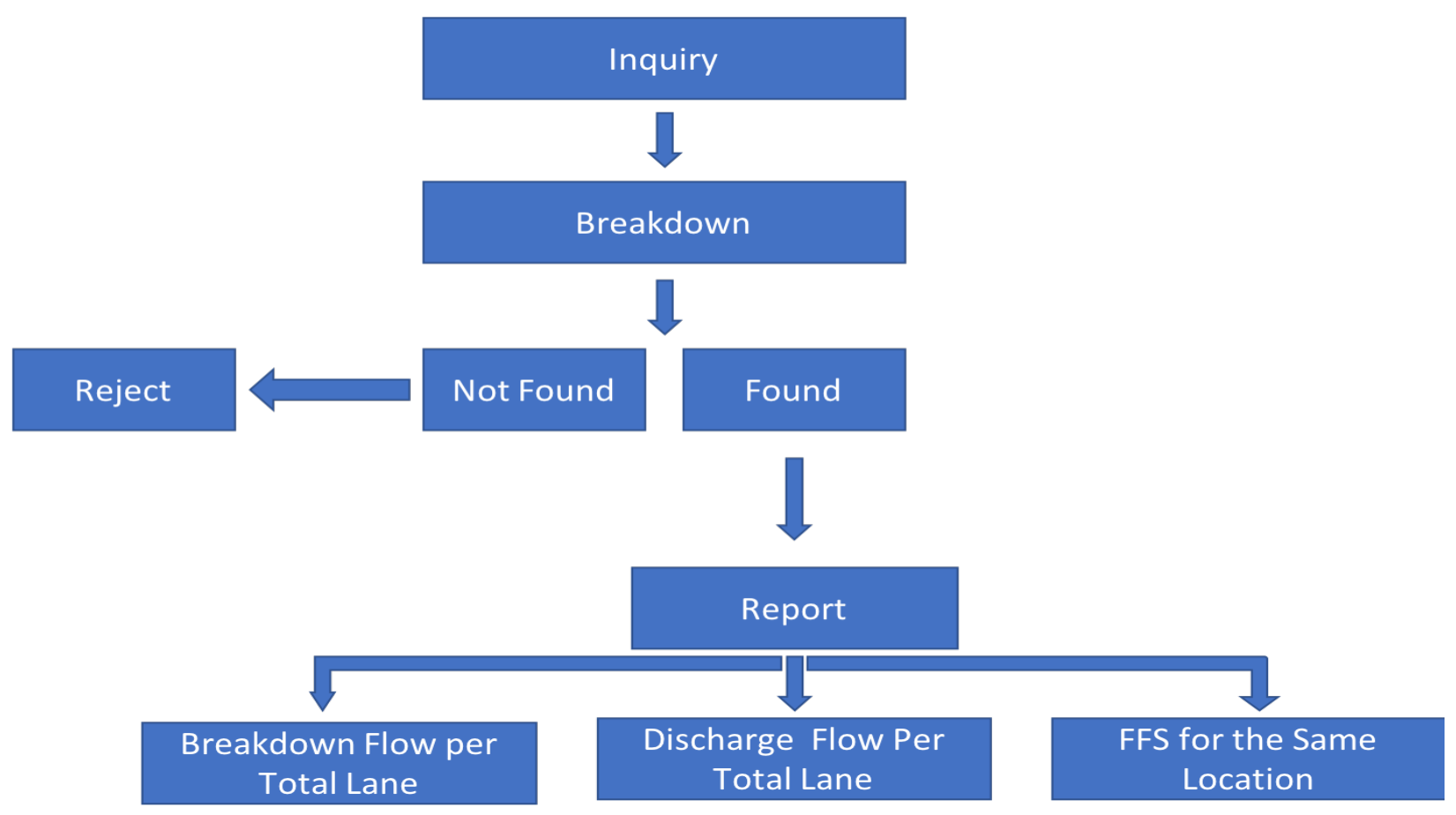

Figure 11 Steps for Reporting an Event

\subsection{Capacity Results}

This section presents the average capacity observed from each detector by facility type (e.g., two-lane freeway). Four conditions are presented here:

1- Observed Pre-Breakdown Flow for Base Conditions.

2- Observed Discharge Flow During Incident Conditions (good weather);

- Incidents Capacity (upstream of closure)

- Incident Capacity (within closure)

3- Observed Pre-Breakdown Flow During Rain (no incidents)

4- Observed Discharge Flow During Rain and Incidents;

- Rain and incidents capacity (upstream of closure)

- Rain and incident capacity (within closure) 


\subsubsection{Capacity for Base Conditions}

The average breakdown flow was used to define capacity during base conditions for two-lane, three-lane, and four-lane freeway segments, as shown in Table 5, Table 6, and Table 7, respectively.

\section{- Two-Lanes}

Twenty-nine events were observed during base conditions for two-lane segments, and these are listed in Table 6. The data were collected at segments along I-70 and I-35. The average breakdown flow was found to be $3,291 \mathrm{veh} / \mathrm{hr}$, while the average breakdown flow per lane was $1,645 \mathrm{veh} / \mathrm{hr} / \mathrm{ln}$.

Table 6 Base Conditions Capacity for Two-Lane Segments (Good Weather No Incidents)

\begin{tabular}{|c|c|c|c|}
\hline Detector & $\begin{array}{l}\text { Number of } \\
\text { Lanes }\end{array}$ & $\begin{array}{c}\text { Breakdown Flow } \\
\text { (veh/hr) }\end{array}$ & $\begin{array}{c}\text { Breakdown Flow per } \\
\text { Lane (veh/hr/ln) }\end{array}$ \\
\hline I-70 E@ @ WEST OF MO7 & 2 & 3352 & 1676 \\
\hline I-70 E@ @EST OF MO7 & 2 & 3685 & 1843 \\
\hline I-70 E @ WEST OF MO7 & 2 & 3026 & 1513 \\
\hline I-70 E@ WEST OF MO7 & 2 & 3552 & 1776 \\
\hline I-70 E@ @EST OF MO7 & 2 & 3348 & 1674 \\
\hline I-35 S @ 159TH STREET & 2 & 2580 & 1290 \\
\hline I-70 E@ @EST OF MO7 & 2 & 3528 & 1764 \\
\hline I-70 E @ WEST OF MO7 & 2 & 3012 & 1506 \\
\hline I-70 E@ WEST OF MO7 & 2 & 3660 & 1830 \\
\hline I-70 E@ @EST OF MO7 & 2 & 3540 & 1770 \\
\hline I-70 E@ @ WEST OF MO7 & 2 & 3327 & 1664 \\
\hline I-70 E@ @EST OF MO7 & 2 & 3324 & 1662 \\
\hline I-70 E@ @EST OF MO7 & 2 & 3359 & 1680 \\
\hline I-70 E@ @EST OF MO7 & 2 & 3144 & 1572 \\
\hline I-70 E@ @EST OF MO7 & 2 & 3359 & 1680 \\
\hline I-70 E@ @ WEST OF MO7 & 2 & 2984 & 1492 \\
\hline I-70 E@ @ WEST OF MO7 & 2 & 3540 & 1770 \\
\hline I-70 E@ @EST OF MO7 & 2 & 3777 & 1889 \\
\hline I-70 E@ @ WEST OF MO7 & 2 & 3613 & 1807 \\
\hline I-70 E@ WEST OF MO7 & 2 & 3108 & 1554 \\
\hline I-70 E@ @EST OF MO7 & 2 & 3627 & 1814 \\
\hline I-70 E@ @EST OF MO7 & 2 & 3760 & 1880 \\
\hline I-70 E@ @EST OF MO7 & 2 & 3168 & 1584 \\
\hline I-35 N@AT PASEO BLVD & 2 & 2448 & 1224 \\
\hline
\end{tabular}




\begin{tabular}{|l|c|c|c|} 
I-35 N @ AT PASEO BLVD & 2 & 3240 & 1620 \\
\hline I-35 N@AT PASEO BLVD & 2 & 2916 & 1458 \\
\hline I-35 N @ AT PASEO BLVD & 2 & 3216 & 1608 \\
\hline I-35 N @ AT PASEO BLVD & 2 & 3107 & 1554 \\
\hline I-35 N @ AT PASEO BLVD & 2 & 3132 & 1566 \\
\hline Average & & 3291 & 1645 \\
\hline Standard Deviation & & 326 & 163 \\
\hline
\end{tabular}

\section{- Three-Lane}

Breakdown flow rates for three-lanes are listed in Table 7. Forty-seven capacity observations were collected during base conditions. Average breakdown flow obtained was 5,237 veh/hr. and average breakdown flow per lane was $1,746 \mathrm{veh} / \mathrm{hr} / \mathrm{ln}$.

Table 7 Base Conditions Capacity for Three-Lane Segments (Good Weather No Incidents)

\begin{tabular}{|c|c|c|c|}
\hline Detector & $\begin{array}{l}\text { Number of } \\
\text { Lanes }\end{array}$ & $\begin{array}{l}\text { Breakdown Flow } \\
\text { (veh/hr) }\end{array}$ & $\begin{array}{l}\text { Breakdown Flow per Lane } \\
\text { (veh/hr/ln) }\end{array}$ \\
\hline I-70 W@ @ BEFORE STADIUM DRIVE & 3 & 5232 & 1744 \\
\hline I-70 W@ BEFORE STADIUM DRIVE & 3 & 5257 & 1752 \\
\hline I-70 W@ NW 19TH STREET & 3 & 4342 & 1447 \\
\hline I-70 W@ BEFORE STADIUM DRIVE & 3 & 5158 & 1719 \\
\hline I-70 W@ @ BEFORE STADIUM DRIVE & 3 & 5672 & 1891 \\
\hline I-70 W@ @ BEFORE STADIUM DRIVE & 3 & 5158 & 1719 \\
\hline I-70 E @ EAST OF BLUE RIDGE & 3 & 5768 & 1923 \\
\hline I-70 E@EAST OF BLUE RIDGE & 3 & 5949 & 1983 \\
\hline I-70 E@EAST OF BLUE RIDGE & 3 & 5615 & 1872 \\
\hline I-70 E @ EAST OF BLUE RIDGE & 3 & 5256 & 1752 \\
\hline I-70E@EAST OF BLUE RIDGE & 3 & 5520 & 1840 \\
\hline I-70E@EAST OF BLUE RIDGE & 3 & 5561 & 1854 \\
\hline I-70 E@ NW SCRIMSHAW RD & 3 & 5673 & 1891 \\
\hline I-70 E@ NW SCRIMSHAW RD & 3 & 4212 & 1404 \\
\hline I-70 E@ NW SCRIMSHAW RD & 3 & 5517 & 1839 \\
\hline I-70E@ NW SCRIMSHAW RD & 3 & 5019 & 1673 \\
\hline I-70E@ NW SCRIMSHAW RD & 3 & 4368 & 1456 \\
\hline I-70W@NW 50TH ST & 3 & 4884 & 1628 \\
\hline I-70W@NW 50TH ST & 3 & 5496 & 1832 \\
\hline I-70W@NW 50TH ST & 3 & 5173 & 1724 \\
\hline I-70W@NW 50TH ST & 3 & 4895 & 1632 \\
\hline I-35 S @ 127TH STREET & 3 & 5498 & 1833 \\
\hline I-35 S @ 127TH STREET & 3 & 4612 & 1537 \\
\hline I-35 S @ 127TH STREET & 3 & 4920 & 1640 \\
\hline I-35 S@127TH STREET & 3 & 5729 & 1910 \\
\hline
\end{tabular}




\begin{tabular}{|l|l|l|l|}
\hline I-35 S @ 127TH STREET & 3 & 6525 & 2175 \\
\hline I-35 S @ QUIVIRA RD & 3 & 3948 & 1316 \\
\hline I-35 S @ QUIVIRA RD & 3 & 4392 & 1464 \\
\hline I-35 S @ 75TH ST & 3 & 5344 & 1781 \\
\hline I-35 S @ 75TH ST & 3 & 5800 & 1933 \\
\hline I-35 S @ 75TH ST & 3 & 5820 & 1940 \\
\hline I-35 S @ LAMAR AVE & 3 & 5736 & 1912 \\
\hline I-35 S @ LAMAR AVE & 3 & 5523 & 1856 \\
\hline I-35 S @ LAMAR AVE & 3 & 5568 & 1971 \\
\hline I-35 S @ LAMAR AVE & 3 & 5913 & 1692 \\
\hline I-35 N @ MISSION ROAD & 3 & 5076 & 1772 \\
\hline I-35 N@ MISSION ROAD & 3 & 5316 & 1724 \\
\hline I-35 N @ MISSION ROAD & 3 & 5172 & 1568 \\
\hline I-35 N @ MISSION ROAD & 3 & 4704 & 1716 \\
\hline I-435 E @ BEFORE QUIVIRA ROAD & 3 & 4872 & 1735 \\
\hline I-435 E @ BEFORE QUIVIRA ROAD & 3 & 5148 & 1584 \\
\hline I-435 W @ SOUTH OF 63RD ST & 3 & 5204 & 1508 \\
\hline I-435 N @ SOUTH OF 210 HIGHWAY & 3 & 4752 & 1589 \\
\hline I-435 N @ SOUTH OF 210 HIGHWAY & 3 & 4524 & 1902 \\
\hline I-435 N @ SOUTH OF 210 HIGHWAY & 3 & 4767 & 1946 \\
\hline I-435 S @ 79TH STREET & 3 & 5706 & 1746 \\
\hline I-435 S @ 79TH STREET & 3 & 5839 & 177 \\
\hline Average & & 5237 & 531 \\
\hline Standard Deviation & & & \\
\hline
\end{tabular}

\section{- Four-Lane}

Pre-breakdown flow data were observed along I-70, I-35, and I-435 as listed in Table 8. Average

breakdown flow observed during base conditions was $6,531 \mathrm{veh} / \mathrm{hr}$, or equivalently 1,633 $\mathrm{veh} / \mathrm{hr} / \mathrm{ln}$.

Table 8 Base Conditions Capacity for Four-Lane Segments (Good Weather No Incidents)

\begin{tabular}{|l|c|c|c|}
\hline Detector & $\begin{array}{c}\text { Number of } \\
\text { Lanes }\end{array}$ & $\begin{array}{c}\text { Breakdown Flow } \\
\text { (veh/hr) }\end{array}$ & $\begin{array}{c}\text { Breakdown Flow per Lane } \\
\text { (veh/hr/ln) }\end{array}$ \\
\hline I-70 E @ AT LITTLE BLUE & 4 & 5424 & 1356 \\
\hline I-70 E @ AT LITTLE BLUE & 4 & 5580 & 1395 \\
\hline I-70 E @ AT LITTLE BLUE & 4 & 5376 & 1344 \\
\hline I-70 E @ BROOKLYN AVE & 4 & 7340 & 1835 \\
\hline I-35 S @ 67TH ST & 4 & 6600 & 1650 \\
\hline I-35 S @67TH ST & 4 & 6819 & 1705 \\
\hline I-35 S @ 67TH ST & 4 & 5754 & 1439 \\
\hline I-35 S @ 67TH ST & 4 & 6562 & 1641 \\
\hline
\end{tabular}




\begin{tabular}{|l|c|c|c|} 
I-35 S @ 67TH ST & 4 & 6802 & 1701 \\
\hline I-35 S @ 67TH ST & 4 & 6636 & 1659 \\
\hline I-35 S @ 67TH ST & 4 & 7277 & 1819 \\
\hline I-35 S @ I-636 & 4 & 6747 & 1687 \\
\hline I-35 S @ I-637 & 4 & 6798 & 1700 \\
\hline I-35 S @ I-640 & 4 & 6864 & 1716 \\
\hline I-35 S @ JOHNSON DR & 4 & 6738 & 1685 \\
\hline I-35 S @ JOHNSON DR & 4 & 5760 & 1440 \\
\hline I-35 S @ JOHNSON DR & 4 & 6744 & 1686 \\
\hline I-35 S @ JOHNSON DR & 4 & 6796 & 1771 \\
\hline $\begin{array}{l}\text { I-435 E @ WEST OF 104TH } \\
\text { ST }\end{array}$ & 4 & 7084 & 1842 \\
\hline $\begin{array}{l}\text { I-435 E @ WEST OF 104TH } \\
\text { ST }\end{array}$ & 4 & 7368 & 1755 \\
\hline $\begin{array}{l}\text { I-435 E @ WEST OF 104TH } \\
\text { ST }\end{array}$ & 4 & 7020 & 1399 \\
\hline I-435 S @ Front Street & 4 & 5594 & 1633 \\
\hline Average & & 6531 & 160 \\
\hline Standard Deviation & & 638 & \\
\hline
\end{tabular}

\subsubsection{Incident Capacity (Good Weather)}

The average discharge flow rate was used to measure capacity during incidents. The first capacity in each table presents the average capacity per the total (open) lanes (veh/hr), which were then converted to the average capacity per open lane during incidents (veh/hr/ln). Each table shows the number of lanes that the facility initially had, and then the number of lanes that were not affected during the incidents. Finally, t-tests were carried out between incidents measured upstream of the lane closure and incidents measured within the lane closure to identify whether the measurement location had an influence on the capacity during incidents.

\section{- Two-lane Incidents Measured Upstream of Lane Closure}

Two-lane incidents measured upstream of lane closure were observed at twelve locations over Kansas City's freeways, as shown in Table 9. The average discharge flow was found to be 2,098 $\mathrm{veh} / \mathrm{hr}$, or $1,098 \mathrm{veh} / \mathrm{hr} / \mathrm{ln}$ per open lane. 
Table 9 Incident Capacity for Two-Lanes Measured Upstream of Closures (Good Weather)

\begin{tabular}{|c|c|c|c|c|}
\hline Detector & $\begin{array}{l}\text { Number } \\
\text { of Lanes }\end{array}$ & $\begin{array}{c}\text { Discharge } \\
\text { flow (veh/hr) }\end{array}$ & $\begin{array}{l}\text { Number of } \\
\text { Open Lanes }\end{array}$ & $\begin{array}{l}\text { Discharge flow per } \\
\text { lane (veh/hr/ln) }\end{array}$ \\
\hline I-70W@23RD ST & 2 & 2832 & 2 & 1416 \\
\hline I-35 S @ BEFORE PASEO BLVD & 2 & 3216 & 2 & 1608 \\
\hline I-70 E @ WEST OF MO7 & 2 & 1656 & 2 & 828 \\
\hline $\begin{array}{l}\text { I-470 S @ NORTH OF WOODS } \\
\text { CHAPEL ROAD }\end{array}$ & 2 & 2556 & 2 & 1278 \\
\hline $\begin{array}{l}\text { US-71 S @ SOUTH OF 75TH } \\
\text { STREET }\end{array}$ & 2 & 1716 & 2 & 858 \\
\hline $\begin{array}{l}\text { I-470 N@ NORTH OF } \\
\text { LAKEWOOD BLVD }\end{array}$ & 2 & 1956 & 2 & 978 \\
\hline US-50 W@CHIPMAN ROAD & 2 & 2628 & 2 & 1314 \\
\hline $\begin{array}{l}\text { I-470 N@ NORTH OF } \\
\text { LAKEWOOD BLVD }\end{array}$ & 2 & 1620 & 2 & 810 \\
\hline I-70E@110TH STREET & 2 & 1176 & 2 & 1176 \\
\hline I-70 E @ EAST OF MO-7 & 2 & 2040 & 2 & 1020 \\
\hline I-70 E @ EAST OF MO-7 & 2 & 1620 & 2 & 810 \\
\hline I-70 E@EAST OF MO-7 & 2 & 2160 & 2 & 1080 \\
\hline Average & & 2098 & & 1098 \\
\hline Standard Deviation & & 680 & & 287 \\
\hline
\end{tabular}




\section{- Two-lanes Incidents Measured Within Lane Closure}

Only six events were found for two-lane incidents measured within a lane closure, as shown in

Table 10. The average discharge flow was $1,111 \mathrm{veh} / \mathrm{h}$ or $1,111 \mathrm{veh} / \mathrm{h} / \mathrm{ln}$.

Table 10 Incident Capacity for Two-Lanes Measured within Closures (Good Weather)

\begin{tabular}{|l|c|c|c|c|}
\hline \multicolumn{1}{|c|}{ Detector } & $\begin{array}{c}\text { Number of } \\
\text { Lanes }\end{array}$ & $\begin{array}{c}\text { Capacity } \\
\text { (veh/hr) }\end{array}$ & $\begin{array}{c}\text { Number of Open } \\
\text { Lanes }\end{array}$ & $\begin{array}{c}\text { Capacity per open lane } \\
\text { (veh/hr/ln) }\end{array}$ \\
\hline I-470 N @ I-70 & 2 & 984 & 1 & 984 \\
\hline $\begin{array}{l}\text { US-69 S @ 135TH STREET } \\
\text { LOOP RAMP }\end{array}$ & 2 & 960 & 1 & 960 \\
\hline I-635 N @ MISSOURI RIVER & 2 & 1284 & 1 & 1284 \\
\hline $\begin{array}{l}\text { I-470 S @ NORTH OF } \\
\text { WOODS CHAPEL ROAD }\end{array}$ & 2 & 1272 & 1 & 1272 \\
\hline US-71 S @75TH STREET & 2 & 1356 & 1 & 810 \\
\hline I-70 E @ EAST OF MO-7 & 2 & 810 & 111 & 111 \\
\hline AVERAGE & & 222 & & 222 \\
\hline STANDARD DEVIATION & & & & 1356 \\
\hline
\end{tabular}

Table 11 shows the results of the t-test. Assuming a 95\% confident interval, the difference between incident capacities measured upstream and within a lane closure is not statistically significant, as the two-tailed p-value is higher than 0.025 . Thus, our analysis showed that the measurement location did not affect the incident capacity results at two-lane segments. As a result, the observations from Table 9 and Table 10 were merged into Table 12.

Table 11 Two-Lanes T-Statistic Between Incidents without Lane Closure and with One Lane Closure

\begin{tabular}{|c|c|c|}
\hline \multicolumn{3}{|c|}{ Capacity } \\
\hline Category & $\begin{array}{c}\text { Incidents Measured } \\
\text { Upstream of Closure }\end{array}$ & $\begin{array}{c}\text { Incidents Measured } \\
\text { Within Closure }\end{array}$ \\
\hline Mean & 1098 & 1111 \\
\hline N & 12 & 6 \\
\hline Std. Deviation & 287 & 222 \\
\hline Std. Error Mean & 83 & 54 \\
\hline
\end{tabular}




\begin{tabular}{|c|c|c|c|}
\cline { 2 - 4 } \multicolumn{1}{c|}{} & $\begin{array}{c}\text { Degrees of } \\
\text { Freedom }\end{array}$ & T-score & P value (2-tailed) \\
\hline $\begin{array}{c}\text { Incidents upstream closure- } \\
\text { incidents within closure }\end{array}$ & 16 & 0.0969 & 0.924 \\
\hline
\end{tabular}

According to Table 12, the average discharge flow per open lane was $1,102 \mathrm{veh} / \mathrm{hr} / \mathrm{ln}$.

Table 12 Incident Capacity for Two-Lanes

\begin{tabular}{|l|c|c|}
\hline Detector & $\begin{array}{c}\text { Number } \\
\text { of Lanes }\end{array}$ & $\begin{array}{c}\text { Discharge Flow per } \\
\text { open lane (veh/hr/ln) }\end{array}$ \\
\hline I-70 W @ 23RD ST & 2 & 1416 \\
\hline I-35 S @ BEFORE PASEO BLVD & 2 & 1608 \\
\hline I-70 E @ WEST OF MO7 & 2 & 828 \\
\hline $\begin{array}{l}\text { I-470 S @ NORTH OF WOODS CHAPEL } \\
\text { ROAD }\end{array}$ & 2 & 1278 \\
\hline US-71 S @ SOUTH OF 75TH STREET & 2 & 858 \\
\hline $\begin{array}{l}\text { I-470 N @ NORTH OF LAKEWOOD } \\
\text { BLVD }\end{array}$ & 2 & 978 \\
\hline US-50 W @ CHIPMAN ROAD & 2 & 1314 \\
\hline $\begin{array}{l}\text { I-470 N @ NORTH OF LAKEWOOD } \\
\text { BLVD }\end{array}$ & 2 & 810 \\
\hline I-70 E @ 110TH STREET & 2 & 1176 \\
\hline I-70 E @ EAST OF MO-7 & 2 & 1020 \\
\hline I-70 E @ EAST OF MO-7 & 2 & 810 \\
\hline I-70 E @ EAST OF MO-7 & 2 & 1080 \\
\hline I-470 N @ I-70 & 2 & 984 \\
\hline US-69 S @135TH STREET LOOP RAMP & 2 & 960 \\
\hline I-635 N @ MISSOURI RIVER & 2 & 1284 \\
\hline $\begin{array}{l}\text { I-470 S @ NORTH OF WOODS CHAPEL } \\
\text { ROAD }\end{array}$ & 2 & 1272 \\
\hline US-71 S @ 75TH STREET & 2 & 1356 \\
\hline I-70E @ EAST OF MO-7 & & 244 \\
\hline Average & 2 & 2 \\
\hline Standard Deviation & 2 & 2 \\
\hline
\end{tabular}




\section{- Three-Lanes Incidents Measured Upstream of Lane Closure}

Twenty-nine locations were found for the three lane segments with incidents measured upstream of the lane closure, as shown in Table 13. The average discharge flow was 3,910 veh/hr and was converted to average discharge flow per open lane as $1,303 \mathrm{veh} / \mathrm{hr} / \mathrm{ln}$.

Table 13 Incident Capacity for Three-Lanes Measured Upstream of Closure (Good Weather)

\begin{tabular}{|c|c|c|c|c|}
\hline Detector & $\begin{array}{l}\text { Number of } \\
\text { Lanes }\end{array}$ & $\begin{array}{l}\text { Discharge } \\
\text { flow (veh/hr) }\end{array}$ & $\begin{array}{l}\text { Number of } \\
\text { Open Lanes }\end{array}$ & $\begin{array}{l}\text { Discharge flow per } \\
\text { open lane (veh/hr/ln) }\end{array}$ \\
\hline $\begin{array}{c}\text { I-70 E @ EAST OF BLUE } \\
\text { RIDGE CUTOFF }\end{array}$ & 3 & 3252 & 3 & 1084 \\
\hline $\begin{array}{c}\text { I-70 E@ NW SCRIMSHAW } \\
\text { RD }\end{array}$ & 3 & 3900 & 3 & 1300 \\
\hline $\begin{array}{c}\text { I-70 E @ NW SCRIMSHAW } \\
\text { RD }\end{array}$ & 3 & 4920 & 3 & 1640 \\
\hline I-35 S@75TH ST & 3 & 5592 & 3 & 1864 \\
\hline I-35 S@75TH ST & 3 & 5064 & 3 & 1688 \\
\hline I-35 S@75TH ST & 3 & 5016 & 3 & 1672 \\
\hline I-35 S@LAMAR AVE & 3 & 3036 & 3 & 1012 \\
\hline I-35 S@LAMAR AVE & 3 & 3612 & 3 & 1204 \\
\hline I-70W@NW 50TH ST & 3 & 4284 & 3 & 1428 \\
\hline I-35 S @ 127TH STREET & 3 & 3348 & 3 & 1116 \\
\hline I-35 S @ 127TH STREET & 3 & 3024 & 3 & 1008 \\
\hline I-35 N@MISSION ROAD & 3 & 3624 & 3 & 1208 \\
\hline I-35 N@MISSION ROAD & 3 & 4104 & 3 & 1368 \\
\hline $\begin{array}{c}\text { I-70 W @ BEFORE STADIUM } \\
\text { DRIVE }\end{array}$ & 3 & 3936 & 3 & 1312 \\
\hline $\begin{array}{c}\text { I-70 E @ EAST OF BLUE } \\
\text { RIDGE CUTOFF }\end{array}$ & 3 & 3804 & 3 & 1268 \\
\hline $\begin{array}{l}\text { I-70 E @ EAST OF BLUE } \\
\text { RIDGE CUTOFF }\end{array}$ & 3 & 4056 & 3 & 1352 \\
\hline I-35 S@75TH ST & 3 & 4128 & 3 & 1376 \\
\hline I-35 S@75TH ST & 3 & 4572 & 3 & 1524 \\
\hline I-35 N@MISSION ROAD & 3 & 3624 & 3 & 1208 \\
\hline I-35 N@MISSION ROAD & 3 & 4152 & 3 & 1384 \\
\hline $\begin{array}{c}\text { I-435 E @ BEFORE QUIVIRA } \\
\text { ROAD }\end{array}$ & 3 & 3420 & 3 & 1140 \\
\hline $\begin{array}{c}\text { I-435 E @ BEFORE QUIVIRA } \\
\text { ROAD }\end{array}$ & 3 & 3024 & 3 & 1008 \\
\hline
\end{tabular}




\begin{tabular}{|c|c|c|c|c|}
\hline $\begin{array}{c}\text { I-435 E @ BEFORE QUIVIRA } \\
\text { ROAD }\end{array}$ & 3 & 3744 & 3 & 1248 \\
\hline $\begin{array}{c}\text { I-70 E @ EAST OF BLUE } \\
\text { RIDGE CUTOFF }\end{array}$ & 3 & 3336 & 3 & 1112 \\
\hline I-70 W @ NW 19TH STREET & 3 & 3336 & 3 & 1112 \\
\hline $\begin{array}{c}\text { I-70 W @ BEFORE STADIUM } \\
\text { DRIVE }\end{array}$ & 3 & 3324 & 3 & 1108 \\
\hline I-35 S @ LAMAR AVE & 3 & 5496 & 3 & 1104 \\
\hline $\begin{array}{c}\text { I-70 E @ EAST OF BLUE } \\
\text { RIDGE CUTOFF }\end{array}$ & 3 & 3312 & 3 & 1112 \\
\hline $\begin{array}{c}\text { I-70 E @ EAST OF } \\
\text { CHRYSLER AVE }\end{array}$ & 3 & 3336 & 3 & 1303 \\
\hline Average & & 3910 & & 244 \\
\hline Standard Deviation & 731 & & \\
\hline
\end{tabular}

\section{- Three-Lanes Incidents Measured Within Lane Closure}

Table 14 shows fifteen incidents measured within the lane closure that were observed at threelane segments at multiple locations across Kansas City. The average discharge flow was 2,613 veh/hr. Additionally, the average discharge flow per open lane was found to be $1,306 \mathrm{veh} / \mathrm{hr} / \mathrm{ln}$.

Table 14 Incident Capacity for Three-Lane Measured Within Lane Closure (Good Weather and One Closure)

\begin{tabular}{|c|c|c|c|c|}
\hline Detector & $\begin{array}{c}\text { Number of } \\
\text { Lanes }\end{array}$ & $\begin{array}{c}\text { discharge flow } \\
\text { (veh/hr) }\end{array}$ & $\begin{array}{c}\text { Number of } \\
\text { Open Lanes }\end{array}$ & $\begin{array}{c}\text { discharge flow per open } \\
\text { lane (veh/hr/ln) }\end{array}$ \\
\hline I-35 S @ 127TH STREET & 3 & 3096 & 2 & 1548 \\
\hline I-35 S @ 127TH STREET & 3 & 3168 & 2 & 1584 \\
\hline I-35 S @ 127TH STREET & 3 & 2196 & 2 & 1098 \\
\hline I-35 S @ 127TH STREET & 3 & 2388 & 2 & 1194 \\
\hline I-35 S @ QUIVIRA RD & 3 & 2712 & 2 & 1356 \\
\hline I-70 E @ NW SCRIMSHAW & 3 & 2016 & 2 & 1254 \\
\hline RD & 3 & 2508 & 2 & 1488 \\
\hline I-70 W @ NW 50TH ST & 3 & 2976 & 2 & 1020 \\
\hline I-35 S @ QUIVIRA RD & 3 & 2040 & 2 & 1212 \\
\hline I-35 N @ MISSION ROAD & 3 & 2424 & 2 & 1356 \\
\hline I-70 W @ NW 50TH ST & 3 & 2712 & 2 & 2 \\
\hline
\end{tabular}




\begin{tabular}{|c|c|c|c|c|} 
I-35 N@MISSION ROAD & 3 & 2652 & 2 & 1326 \\
\hline $\begin{array}{c}\text { I-70 E @ EAST OF BLUE } \\
\text { RIDGE CUTOFF }\end{array}$ & 3 & 2052 & 2 & 1026 \\
\hline $\begin{array}{c}\text { I-470 W @ VIEW HIGH } \\
\text { ROAD }\end{array}$ & 3 & 3156 & 2 & 1578 \\
\hline I-35 N@ ANTIOCH RD & 3 & 3096 & 2 & 1548 \\
\hline Average & & 2613 & & 1306 \\
\hline Standard Deviation & & 422 & & 211 \\
\hline
\end{tabular}

T-test results shown in Table 15 indicated that the difference between incident capacities measured upstream and within the lane closure is not statistically significant as the p-value is greater than 0.025 . Thus, our analysis indicated that the measurement location did not have a significant effect on the capacity at three-lane segments evaluated during incidents at the study locations. A new table was therefore, developed to combine the observations from Table 13 and Table 14 into Table 16.

Table 15 Three-Lanes T-Statistic Between Incidents Measured Upstream and Within Lane Closure

\begin{tabular}{|c|c|c|}
\hline \multicolumn{2}{|c|}{ Capacity } \\
\hline Category & $\begin{array}{c}\text { Incidents Measured } \\
\text { Upstream of Closure }\end{array}$ & $\begin{array}{c}\text { Incidents Measured } \\
\text { Within Closure }\end{array}$ \\
\hline Mean & 1303 & 1306 \\
\hline $\mathrm{N}$ & 29 & 15 \\
\hline Std. Deviation & 244 & 211 \\
\hline Std. Error Mean & 45 & 55 \\
\hline
\end{tabular}

\begin{tabular}{|l|c|c|c|}
\cline { 2 - 4 } \multicolumn{1}{c|}{} & $\begin{array}{l}\text { Degree of } \\
\text { Freedom }\end{array}$ & T-score & P value (2-tailed) \\
\hline $\begin{array}{l}\text { Incidents upstream closure- } \\
\text { incidents within closure }\end{array}$ & 42 & 0.0404 & 0.968 \\
\hline
\end{tabular}

The results shown in Table 16 were retrieved from combining Table 13 and Table 14. The average discharge flow per open lane was $1,304 \mathrm{veh} / \mathrm{hr} / \mathrm{ln}$. 
Table 16 Three-Lanes Incidents Capacity

\begin{tabular}{|c|c|c|}
\hline Detector & $\begin{array}{l}\text { Number of } \\
\text { Lanes }\end{array}$ & $\begin{array}{c}\text { Discharge Flow per open } \\
\text { lane }(\mathrm{veh} / \mathrm{hr} / \mathrm{ln})\end{array}$ \\
\hline I-70 E@EAST OF BLUE RIDGE CUTOFF & 3 & 1084 \\
\hline I-70E@ NW SCRIMSHAW RD & 3 & 1300 \\
\hline I-70E@NW SCRIMSHAW RD & 3 & 1640 \\
\hline I-35 S@75TH ST & 3 & 1864 \\
\hline I-35 S@75TH ST & 3 & 1688 \\
\hline I-35 S@75TH ST & 3 & 1672 \\
\hline I-35 S@LAMAR AVE & 3 & 1012 \\
\hline I-35 S@LAMAR AVE & 3 & 1204 \\
\hline I-70W@NW 50TH ST & 3 & 1428 \\
\hline I-35 S@127TH STREET & 3 & 1116 \\
\hline I-35 S@127TH STREET & 3 & 1008 \\
\hline I-35 N@MISSION ROAD & 3 & 1208 \\
\hline I-35 N@MISSION ROAD & 3 & 1368 \\
\hline I-70W@BEFORE STADIUM DRIVE & 3 & 1312 \\
\hline I-70E@EAST OF BLUE RIDGE CUTOFF & 3 & 1268 \\
\hline I-70 E@ EAST OF BLUE RIDGE CUTOFF & 3 & 1352 \\
\hline I-35 S@75TH ST & 3 & 1376 \\
\hline I-35 S@75TH ST & 3 & 1524 \\
\hline I-35N@MISSION ROAD & 3 & 1208 \\
\hline I-35 N@MISSION ROAD & 3 & 1384 \\
\hline I-435 E@BEFORE QUIVIRA ROAD & 3 & 1140 \\
\hline I-435 E@BEFORE QUIVIRA ROAD & 3 & 1008 \\
\hline I-435 E@BEFORE QUIVIRA ROAD & 3 & 1248 \\
\hline I-70 E @EAST OF BLUE RIDGE CUTOFF & 3 & 1112 \\
\hline I-70W@NW 19TH STREET & 3 & 1112 \\
\hline I-70W@BEFORE STADIUM DRIVE & 3 & 1108 \\
\hline I-35 S@LAMAR AVE & 3 & 1832 \\
\hline I-70 E @EAST OF BLUE RIDGE CUTOFF & 3 & 1104 \\
\hline I-70E@EAST OF CHRYSLER AVE & 3 & 1112 \\
\hline I-35 S@127TH STREET & 3 & 1548 \\
\hline I-35 S@127TH STREET & 3 & 1584 \\
\hline I-35 S@127TH STREET & 3 & 1098 \\
\hline I-35 S@127TH STREET & 3 & 1194 \\
\hline I-35 S @ QUIVIRA RD & 3 & 1356 \\
\hline I-70 E @ NW SCRIMSHAW RD & 3 & 1008 \\
\hline I-70W@NW 50TH ST & 3 & 1254 \\
\hline
\end{tabular}




\begin{tabular}{|l|c|c|} 
I-35 S @ QUIVIRA RD & 3 & 1488 \\
\hline I-35 N @ MISSION ROAD & 3 & 1020 \\
\hline I-35 S @ 75TH ST & 3 & 1212 \\
\hline I-70 W @ NW 50TH ST & 3 & 1356 \\
\hline I-35 N @ MISSION ROAD & 3 & 1326 \\
\hline I-70 E @ EAST OF BLUE RIDGE CUTOFF & 3 & 1026 \\
\hline I-470 W @ VIEW HIGH ROAD & 3 & 1578 \\
\hline I-35 N @ ANTIOCH RD & 3 & 1548 \\
\hline Average & & 1304 \\
\hline Standard Deviation & & 231 \\
\hline
\end{tabular}

\section{- Four-Lanes Incidents Measured Upstream of Lane Closure}

Incidents measured upstream of lane closure during good weather were obtained from twentyfour detectors located on several freeways across Kansas City. The majority of the events were observed on I-35. The average discharge flow was 5,001 veh/hr and the average discharge flow per lane was $1,250 \mathrm{veh} / \mathrm{hr} / \mathrm{ln}$ (Table 17$)$.

Table 17 Incident Capacity for Four-Lanes Measured Upstream of Closures (Good Weather)

\begin{tabular}{|c|c|c|c|c|}
\hline Detector & $\begin{array}{c}\text { Number of } \\
\text { Lanes }\end{array}$ & $\begin{array}{c}\text { Discharge Flow } \\
\text { (veh/hr) }\end{array}$ & $\begin{array}{c}\text { Number of Open } \\
\text { Lanes }\end{array}$ & $\begin{array}{c}\text { Discharge flow per } \\
\text { open lane (veh/hr/ln) }\end{array}$ \\
\hline I-70 E @ AT LITTLE BLUE & 4 & 4152 & 4 & 1038 \\
\hline I-35 S @ 67TH ST & 4 & 5316 & 4 & 1329 \\
\hline I-35 S @ I-635 & 4 & 5364 & 4 & 1341 \\
\hline I-35 S @67TH ST & 4 & 5292 & 4 & 1125 \\
\hline I-35 S @ 67TH ST & 4 & 4500 & 4 & 1332 \\
\hline I-35 S @67TH ST & 4 & 5328 & 4 & 1257 \\
\hline I-35 S @67TH ST & 4 & 5028 & 4 & 1389 \\
\hline I-35 S @67TH ST & 4 & 5256 & 4 & 1194 \\
\hline I-35 S @67TH ST & 4 & 5556 & 4 & 1104 \\
\hline I-35 S @ I-635 & 4 & 4776 & 4 & 1086 \\
\hline I-35 S @ I-635 & 4 & 4416 & 4 & 4344 \\
\hline I-35 S @ JOHNSON DR & 4 & 4344 & 4 & 4 \\
\hline
\end{tabular}




\begin{tabular}{|c|c|c|c|c|}
\hline I-435 E @ WEST OF 104TH ST & 4 & 5172 & 4 & 1293 \\
\hline I-435 E @ STATE LINE RD & 4 & 5988 & 4 & 1497 \\
\hline I-35 S @ 67TH ST & 4 & 4896 & 4 & 1551 \\
\hline I-35 S @ I-635 & 4 & 6204 & 4 & 1212 \\
\hline I-35 S @ I-635 & 4 & 4848 & 4 & 1059 \\
\hline I-35 S @ 67TH ST & 4 & 4236 & 4 & 1005 \\
\hline I-35 S @ 67TH ST & 4 & 4020 & 4 & 1224 \\
\hline I-35 S @ 67TH ST & 4 & 4296 & 4 & 1143 \\
\hline I-35 S @ I-635 & 4 & 4896 & 4 & 1539 \\
\hline I-435 E @ WEST OF 104TH ST & 4 & 4572 & 4 & 1350 \\
\hline I-435 E @ STATE LINE RD & 4 & 6156 & 5400 & 155 \\
\hline I-35 N @ NORTH OF ROE AVE & 4 & 5001 & 619 & 4 \\
\hline Average & & 4400 & 4 \\
\hline Standard Deviation & & 4 & 4 & 4 \\
\hline
\end{tabular}

\section{- Four-Lanes Incidents Measured Within Lane Closure}

Over fifteen locations shown in Table 18 include four-lanes incidents measured within the lane closure at I-35, I-70, and I-435. It was found that the average discharge flow (i.e., capacity) was $3,807 \mathrm{veh} / \mathrm{hr}$, and the average discharge flow per open lane was $1,269 \mathrm{veh} / \mathrm{hr} / \mathrm{ln}$.

Table 18 Incident Capacity for Four-Lane with One Lane Closures (Good Weather)

\begin{tabular}{|c|c|c|c|c|}
\hline Detector & $\begin{array}{l}\text { Number } \\
\text { of Lanes }\end{array}$ & $\begin{array}{l}\text { Discharge } \\
\text { Flow } \\
\text { (veh/hr) }\end{array}$ & $\begin{array}{l}\text { Number of Open } \\
\text { Lanes }\end{array}$ & $\begin{array}{l}\text { Discharge flow per } \\
\text { open lane (veh/hr/ln) }\end{array}$ \\
\hline I-70 E @ AT LITTLE BLUE & 4 & 3744 & 3 & 1248 \\
\hline $\begin{array}{c}\text { I-70 W @ AT LITTLE BLUE } \\
\text { RIVER } \\
\end{array}$ & 4 & 3660 & 3 & 1220 \\
\hline I-435 E@ WEST OF 104TH ST & 4 & 4008 & 3 & 1336 \\
\hline I-70 E@AT LITTLE BLUE & 4 & 4356 & 3 & 1452 \\
\hline $\begin{array}{l}\text { I-70 W@ AT LITTLE BLUE } \\
\text { RIVER }\end{array}$ & 4 & 3108 & 3 & 1036 \\
\hline $\begin{array}{c}\text { I-70 W @ AT LITTLE BLUE } \\
\text { RIVER }\end{array}$ & 4 & 3912 & 3 & 1304 \\
\hline
\end{tabular}




\begin{tabular}{|c|c|c|c|c|}
\hline I-35 S @ 67TH ST & 4 & 4836 & 3 & 1612 \\
\hline I-35 S @ I-635 & 4 & 3240 & 3 & 1080 \\
\hline I-35 S @ JOHNSON DR & 4 & 3204 & 3 & 1416 \\
\hline I-435 E @ WEST OF 104TH ST & 4 & 4248 & 3 & 1340 \\
\hline I-70 E @ BROOKLYN AVE & 4 & 4020 & 3 & 1276 \\
\hline I-70 W @ AT LITTLE BLUE & 4 & 3828 & 3 & 1140 \\
\hline RIVER & 4 & 3420 & 3 & 1408 \\
\hline I-70 E @ BROOKLYN AVE & 4 & 3300 & 4224 & 1269 \\
\hline I-35 S @ ANTIOCH RD & 4 & 3807 & & 165 \\
\hline Average & & 495 & 3 & 3 \\
\hline Standard Deviation & & 45 OF 104TH ST & & 3 \\
\hline
\end{tabular}

Table 19 displays the results from the t-test. With a 95\% confidence interval, the results indicated that the difference between incident capacities measured upstream and within the lane closure is not statistically significant. As a result, the analysis from this thesis indicated that the measurement location did not have a significant effect on the capacity at four-lane segments evaluated during incidents at the study locations. Thus, a new table was created by combining the values from Table 17and Table 18 .

Table 19 Four-Lanes T-Statistic Between Incidents Measured Upstream and Within Lane Closure

\begin{tabular}{|c|c|c|}
\hline \multicolumn{3}{|c|}{ Capacity } \\
\hline Category & $\begin{array}{c}\text { Incidents Measured } \\
\text { Upstream of Closure }\end{array}$ & $\begin{array}{c}\text { Incidents Measured } \\
\text { Within Closure }\end{array}$ \\
\hline Mean & 1250 & 1269 \\
\hline $\mathrm{N}$ & 24 & 15 \\
\hline Std. Deviation & 155 & 165 \\
\hline Std. Error Mean & 32 & 37 \\
\hline
\end{tabular}




\begin{tabular}{|l|c|c|c|}
\cline { 2 - 4 } \multicolumn{1}{c|}{} & $\begin{array}{l}\text { Degree of } \\
\text { Freedom }\end{array}$ & T-score & P value (2-tailed) \\
\hline $\begin{array}{l}\text { Incidents upsteam closure- } \\
\text { incidents within closure }\end{array}$ & 37 & 0.3634 & 0.7184 \\
\hline
\end{tabular}

According to the combined results shown in Table 20, the average discharge flow per lane was $1,257 \mathrm{veh} / \mathrm{hr} / \mathrm{ln}$.

Table 20 Four-Lanes Incidents Capacity

\begin{tabular}{|c|c|c|}
\hline Detector & Number of Lanes & $\begin{array}{l}\text { Discharge Flow per open lane } \\
(\mathrm{veh} / \mathrm{hr} / \mathrm{ln})\end{array}$ \\
\hline I-70 E @ AT LITTLE BLUE & 4 & 1038 \\
\hline I-35 S@67TH ST & 4 & 1329 \\
\hline I-35 S @ I-635 & 4 & 1341 \\
\hline I-35 S @ 67TH ST & 4 & 1323 \\
\hline I-35 S@67TH ST & 4 & 1125 \\
\hline I-35 S@67TH ST & 4 & 1332 \\
\hline I-35 S@,67TH ST & 4 & 1257 \\
\hline I-35 S @ 67TH ST & 4 & 1314 \\
\hline I-35 S@67TH ST & 4 & 1389 \\
\hline I-35 S @ I-635 & 4 & 1194 \\
\hline I-35 S@ I-635 & 4 & 1104 \\
\hline I-35 S@ JOHNSON DR & 4 & 1086 \\
\hline I-435 E @ WEST OF 104TH ST & 4 & 1293 \\
\hline I-435 E@STATE LINE RD & 4 & 1497 \\
\hline I-35 S@67TH ST & 4 & 1224 \\
\hline I-35 S@ I-635 & 4 & 1551 \\
\hline I-35 S @ I-635 & 4 & 1212 \\
\hline I-35 S @,67TH ST & 4 & 1059 \\
\hline I-35 S@,67TH ST & 4 & 1005 \\
\hline I-35 S @ 67TH ST & 4 & 1074 \\
\hline I-35 S@ I-635 & 4 & 1224 \\
\hline I-435 E @ WEST OF 104TH ST & 4 & 1143 \\
\hline I-435 E @, STATE LINE RD & 4 & 1539 \\
\hline I-35 N@NORTH OF ROE AVE & 4 & 1350 \\
\hline
\end{tabular}




\begin{tabular}{|l|l|l|}
\hline I-70 E @ AT LITTLE BLUE & 4 & 1248 \\
\hline I-70 W @ AT LITTLE BLUE RIVER & 4 & 1220 \\
\hline I-435 E @ WEST OF 104TH ST & 4 & 1336 \\
\hline I-70 E @ AT LITTLE BLUE & 4 & 1452 \\
\hline I-70 W @ AT LITTLE BLUE RIVER & 4 & 1036 \\
\hline I-70 W @ AT LITTLE BLUE RIVER & 4 & 1304 \\
\hline I-35 S @ 67TH ST & 4 & 1612 \\
\hline I-35 S @ I-635 & 4 & 1080 \\
\hline I-35 S @ JOHNSON DR & 4 & 1068 \\
\hline I-435 E @ WEST OF 104TH ST & 4 & 1416 \\
\hline I-70 E @ BROOKLYN AVE & 4 & 1276 \\
\hline I-70 W @ AT LITTLE BLUE RIVER & 4 & 1140 \\
\hline I-70 E @ BROOKLYN AVE & 4 & 1100 \\
\hline I-435 E @ WEST OF 104TH ST & 4 & 1408 \\
\hline I-35 S @ ANTIOCH RD & 4 & 1257 \\
\hline Average & & 157 \\
\hline Standard Deviation & & \\
\hline
\end{tabular}

In summary, the measurement location during an incident was not found to affect the good weather incident capacity, irrespective of the number of freeway lanes.

\subsubsection{Capacity for Adverse Weather (Rain and No Incidents)}

The capacity measurement during rain and no incidents is the same as the base conditions as the average pre-breakdown flow rate was used for that measurement. Also, the average prebreakdown flow per lane was calculated and listed in Table 20, Table 21, and Table 23. 


\section{- Two-Lanes}

Table 21 shows the thirteen events obtained during congestion with rain at two-lane freeways.

The average breakdown flow (i.e., capacity) was 3,248 veh/hr. Also, average capacity per lane was $1,624 \mathrm{veh} / \mathrm{hr} / \mathrm{ln}$.

Table 21 Two-Lane Capacity During Adverse Weather (Rain) and no Incidents

\begin{tabular}{|c|c|c|c|}
\hline Detector & $\begin{array}{l}\text { Number of } \\
\text { Lanes }\end{array}$ & $\begin{array}{l}\text { Breakdown Flow } \\
\text { (veh/hr) }\end{array}$ & $\begin{array}{l}\text { Breakdown Flow } \\
\text { (veh/hr/ln) }\end{array}$ \\
\hline US-50W@291 HIGHWAY NORTH & 2 & 3169 & 1585 \\
\hline I-70E@WEST OF MO7 & 2 & 3564 & 1782 \\
\hline I-35 S@159TH STREET & 2 & 2364 & 1182 \\
\hline I-35 S@159TH STREET & 2 & 2580 & 1290 \\
\hline US-69N@119TH STREET & 2 & 3456 & 1728 \\
\hline US-69 N@119TH STREET & 2 & 2844 & 1422 \\
\hline US-69N@COLLEGE & 2 & 3468 & 1734 \\
\hline US-69 N@COLLEGE & 2 & 3060 & 1530 \\
\hline US-69N@COLLEGE & 2 & 3132 & 1566 \\
\hline US-69N@COLLEGE & 2 & 3984 & 1992 \\
\hline US-69N@COLLEGE & 2 & 3528 & 1764 \\
\hline $\begin{array}{l}\text { US-71 S @ SOUTH OF 75TH } \\
\text { STREET }\end{array}$ & 2 & 3336 & 1668 \\
\hline $\begin{array}{l}\text { US-71 S @ SOUTH OF 75TH } \\
\text { STREET }\end{array}$ & 2 & 3744 & 1872 \\
\hline AVERAGE & & 3248 & 1624 \\
\hline Standard Deviation & & 457 & 229 \\
\hline
\end{tabular}




\section{- Three-Lanes}

Several detectors located at three-lane freeways across Kansas City collected the traffic data for congestion during rain. The data were then summarized in Table 22. Twenty events were observed during rain and no incidents. The average breakdown flow (i.e., capacity) was 5,078 $\mathrm{veh} / \mathrm{hr}$, or $1,693 \mathrm{veh} / \mathrm{hr} / \mathrm{ln}$.

Table 22 Three-Lane Capacity During Adverse Weather (Rain) and no Incidents

\begin{tabular}{|l|c|c|c|}
\hline \multicolumn{1}{|c|}{ Detector } & Number of Lanes & $\begin{array}{c}\text { Breakdown Flow } \\
(\mathrm{veh} / \mathrm{hr})\end{array}$ & $\begin{array}{c}\text { Breakdown Flow } \\
\text { (veh/hr/ln) }\end{array}$ \\
\hline I-70 W @ NOLAND ROAD & 3 & 4680 & 1560 \\
\hline I-70 W @ NOLAND ROAD & 3 & 4992 & 1664 \\
\hline I-70 W @ NOLAND ROAD & 3 & 5071 & 1690 \\
\hline I-70 W @ NW 50TH ST & 3 & 4344 & 1448 \\
\hline I-35 S @ 75TH ST & 3 & 5316 & 1772 \\
\hline I-35 S @ 75TH ST & 3 & 4296 & 1432 \\
\hline I-35 S @ 75TH ST & 3 & 6369 & 2123 \\
\hline I-35 S @ LAMAR AVE & 3 & 5688 & 1896 \\
\hline I-35 S @ LAMAR AVE & 3 & 5208 & 1736 \\
\hline I-35 S @ LAMAR AVE & 3 & 5052 & 1784 \\
\hline I-35 S @ LAMAR AVE & 3 & 5271 & 1436 \\
\hline I-35 N @ NORTH OF I-435 & 3 & 4308 & 1797 \\
\hline I-435 S @ 79TH STREET & 3 & 5390 & 1460 \\
\hline I-35 S @ LAMAR AVE & 3 & 4380 & 1556 \\
\hline I-35 S @ LAMAR AVE & 3 & 4668 & 2025 \\
\hline I-35 S @ 127th Street & 3 & 6075 & 1636 \\
\hline I-435 S @ 79TH STREET & 3 & 4907 & 1812 \\
\hline I-70 W @ NW 50TH ST & 3 & 5436 & 1834 \\
\hline I-35 S @ 75TH ST & 3 & 5503 & 1636 \\
\hline I-35 S @ 75TH ST & 3 & 4608 & 193 \\
\hline AVERAGE & & 5078 & \\
\hline Standard Deviation & & 579 & \\
\hline
\end{tabular}

\section{- Four-Lanes}

The average four-lanes capacity during rain and no incidents obtained from sixteen locations was $6,505 \mathrm{veh} / \mathrm{hr}$, while the per-lane capacity was $1,626 \mathrm{veh} / \mathrm{hr} / \mathrm{ln}$ (Table 23). 
Table 23 Four-Lane Capacity During Adverse Weather (Rain) and no Incidents

\begin{tabular}{|l|c|c|c|}
\hline Detector & $\begin{array}{c}\text { Number of } \\
\text { Lanes }\end{array}$ & $\begin{array}{c}\text { Breakdown Flow } \\
\text { (veh/hr) }\end{array}$ & $\begin{array}{c}\text { Breakdown Flow } \\
\text { (veh/hr/ln })\end{array}$ \\
\hline I-70 E @ BROOKLYN AVE & 4 & 6012 & 1503 \\
\hline I-35 S @ I-635 & 4 & 6917 & 1729 \\
\hline I-35 S @ I-635 & 4 & 5856 & 1464 \\
\hline I-35 S @ JOHNSON DR & 4 & 6468 & 1617 \\
\hline I-35 S @ JOHNSON DR & 4 & 5484 & 1371 \\
\hline I-35 S @ JOHNSON DR & 4 & 5436 & 1359 \\
\hline I-35 S @ JOHNSON DR & 4 & 5616 & 1404 \\
\hline I-435 W @ WEST OF WORNALL RD & 4 & 6819 & 1705 \\
\hline I-435 W @ WEST OF WORNALL RD & 4 & 7416 & 1854 \\
\hline I-435 W @ WEST OF WORNALL RD & 4 & 7504 & 1876 \\
\hline I-435 E @ STATE LINE RD & 4 & 6649 & 1662 \\
\hline I-435 E @ STATE LINE RD & 4 & 6881 & 1720 \\
\hline I-435 E @ STATE LINE RD & 4 & 6336 & 1784 \\
\hline I-435 E @ STATE LINE RD & 4 & 7135 & 1662 \\
\hline I-435 E @ WEST OF 104TH ST & 4 & 6648 & 1725 \\
\hline I-435 E @ WEST OF 104TH ST & 4 & 6900 & 1626 \\
\hline AVERAGE & & 6505 & 165 \\
\hline Standard Deviation & & 658 & \\
\hline
\end{tabular}

In this section, the average per lane pre-breakdown flow was observed during rain and no incidents for two, three, and four lanes. Average capacity during adverse weather (rain) and no incidents for two lanes was $1624 \mathrm{veh} / \mathrm{hr} / \mathrm{ln}$. Similarly, the average capacity for three and four lanes was found to be $1693 \mathrm{veh} / \mathrm{hr} / \mathrm{ln}$ and $1626 \mathrm{veh} / \mathrm{hr} / \mathrm{ln}$, respectively. 


\subsubsection{Capacity for Adverse Weather (Rain) and Incidents}

The average discharge flow was used to identify the capacity during incidents and rain.

Furthermore, the average discharge flow per open lane is shown in Tables 23 through 31.

Finally, t-tests were carried out to compare average discharge flow during incidents measured upstream or within the closure for two, three, and four lanes.

\section{- Two-Lanes Capacity for Rain and Incidents Measured Upstream of Lane Closure}

As shown in Table 24, ten observations were found in this category of incidents measured upstream of closure during rain. The average discharge flow (i.e., capacity) was $2,114 \mathrm{veh} / \mathrm{hr}$. The average per lane capacity was $1,057 \mathrm{veh} / \mathrm{hr} / \mathrm{ln}$.

Table 24 Rain and Incidents Capacity for Two-Lane (Measured Upstream of Closure)

\begin{tabular}{|l|c|c|c|c|}
\hline \multicolumn{1}{|c|}{ Detector } & $\begin{array}{c}\text { Number of } \\
\text { Lanes }\end{array}$ & $\begin{array}{c}\text { Discharge } \\
\text { Flow (veh/hr) }\end{array}$ & $\begin{array}{c}\text { Number of } \\
\text { Open Lanes }\end{array}$ & $\begin{array}{c}\text { Discharge Flow per } \\
\text { open lane } \\
\text { (veh/hr/ln) }\end{array}$ \\
\hline I-35 S @ 159TH STREET & 2 & 2292 & 2 & 1146 \\
\hline US-69 N @ 135TH STREET & 2 & 2016 & 2 & 1008 \\
\hline I-70 E @ I-435 & 2 & 2220 & 2 & 1110 \\
\hline $\begin{array}{l}\text { I-470 N @ NORTH OF } \\
\text { LAKEWOOD }\end{array}$ & 2 & 1572 & 2 & 786 \\
\hline K-10 W @ RIDGEVIEW & 2 & 1452 & 2 & 726 \\
\hline I-70 W @ ADMIRAL BLVD & 2 & 2484 & 2 & 1242 \\
\hline US-69 N @ COLLEGE & 2 & 1872 & 2 & 936 \\
\hline K-10 W @ AT RENNER ROAD & 2 & 2688 & 2 & 1344 \\
\hline I-35 N @ 167TH STREET & 2 & 2328 & 2 & 1164 \\
\hline $\begin{array}{l}\text { K-10 E @ WEST OF } \\
\text { RIDGEVIEW }\end{array}$ & 2 & 2220 & 2 & 1110 \\
\hline Average & & 2114 & & 1057 \\
\hline Standard Deviation & & 390 & & 195 \\
\hline
\end{tabular}

\section{- Two-Lanes Rain and Incidents Measured Within Lane Closure}

Only six events were collected for the two-lanes with incidents during rain measured within the lane closure (Table 25). The average discharge flow was $1,436 \mathrm{veh} / \mathrm{hr}$. The average discharge flow per remaining lanes (i.e., one lane) was $1,436 \mathrm{veh} / \mathrm{hr} / \mathrm{ln}$. 
Table 25 Rain and Incidents Capacity for Two-Lane (One Lane Closure)

\begin{tabular}{|l|c|c|c|c|}
\hline \multicolumn{1}{|c|}{ Detector } & $\begin{array}{c}\text { Number } \\
\text { of } \\
\text { Lanes }\end{array}$ & $\begin{array}{c}\text { Discharge Flow } \\
\text { (veh/hr) }\end{array}$ & $\begin{array}{c}\text { Number of } \\
\text { Open Lanes }\end{array}$ & $\begin{array}{c}\text { Discharge Flow per } \\
\text { open lane (veh/hr/ln) }\end{array}$ \\
\hline I-470 S @ I-70 & 2 & 1176 & 1 & 1176 \\
\hline K-10 E @ WEST OF RENNER RD & 2 & 1488 & 1 & 1488 \\
\hline I-70 E @ I-MILL ST & 2 & 1176 & 1 & 1176 \\
\hline I-35 S @ 159TH STREET & 2 & 1620 & 1 & 1620 \\
\hline $\begin{array}{l}\text { K-10 W @ WEST OF } \\
\text { RIDGEVIEW }\end{array}$ & 2 & 1536 & 1 & 1536 \\
\hline I-35 S @ 159TH STREET & 2 & 1620 & 1 & 1620 \\
\hline Average & & 1436 & & 1436 \\
\hline Standard Deviation & & 208 & & 208 \\
\hline
\end{tabular}

T-tests were applied to identify whether the difference between the two measurement locations during incidents and rain was statistically significant. According to Table 26, the resulting pvalue equals 0.0025 , which is much less than 0.025 . Thus, the difference is considered to be statistically significant.

Table 26 Two-Lanes T-Statistic Between Incidents during Rain Measured Upstream and Within the Lane Closure

\begin{tabular}{|c|c|c|}
\hline \multicolumn{2}{|c|}{ Capacity } \\
\hline Category & $\begin{array}{c}\text { Incidents Measured } \\
\text { Upstream of Closure }\end{array}$ & $\begin{array}{c}\text { Incidents Measured } \\
\text { Within Closure }\end{array}$ \\
\hline Mean & 1057 & 1436 \\
\hline $\mathrm{N}$ & 10 & 6 \\
\hline Std. Deviation & 195 & 208 \\
\hline Std. Error Mean & 62 & 85 \\
\hline
\end{tabular}

\begin{tabular}{|c|c|c|c|}
\cline { 2 - 4 } \multicolumn{1}{c|}{} & $\begin{array}{c}\text { Degree of } \\
\text { Freedom }\end{array}$ & T-score & P value (2-tailed) \\
\hline $\begin{array}{c}\text { Incidents upstream closure- } \\
\text { incidents within closure }\end{array}$ & 14 & 3.6744 & 0.0025 \\
\hline
\end{tabular}

The two-tailed p-value indicated that the impact of measurement location on the capacities of segments during incidents and rainy conditions is significant. 


\section{- Three-Lanes Rain and Incidents Measured Upstream of Lane Closure}

Table 27 shows the observed three-lanes incidents capacity obtained during rain from eleven locations. Several detectors located along I-70 Eastbound and Westbound and I-435 Northbound, Southbound, and Westbound were used to obtain the data. The average discharge flow was 3,142 $\mathrm{veh} / \mathrm{hr}$, and the average capacity per open lane was $1,047 \mathrm{veh} / \mathrm{hr} / \mathrm{ln}$.

Table 27 Rain and Incidents Capacity for Three-Lane (Upstream of Closure)

\begin{tabular}{|l|c|c|c|c|}
\hline \multicolumn{1}{|c|}{ Detector } & $\begin{array}{c}\text { Number } \\
\text { of Lanes }\end{array}$ & $\begin{array}{c}\text { Discharge Flow } \\
\text { (veh/hr) }\end{array}$ & $\begin{array}{c}\text { Number of } \\
\text { Open Lanes }\end{array}$ & $\begin{array}{c}\text { Discharge Flow per open } \\
\text { lane (veh/hr/ln) }\end{array}$ \\
\hline I-70 E @ 31ST ST & 3 & 3636 & 3 & 1212 \\
\hline I-70 E @ East of Chrysler Ave & 3 & 3600 & 3 & 1200 \\
\hline I-70 W @ 23RD ST & 3 & 4008 & 3 & 1336 \\
\hline I-70 E @ LISTER AVE & 3 & 3156 & 3 & 1052 \\
\hline I-435 N @ South of Winner Rd & 3 & 2760 & 3 & 920 \\
\hline I-70 E @ LISTER AVE & 3 & 2748 & 3 & 916 \\
\hline I-435 S @ 79TH STREET & 3 & 3096 & 3 & 1032 \\
\hline I-435 S @ STADIUM DRIVE & 3 & 2736 & 3 & 912 \\
\hline I-435 W @ GREGORY BLVD & 3 & 2952 & 3 & 984 \\
\hline I-70 W @ I-470 & 3 & 3000 & 3 & 1000 \\
\hline INTERCHANGE & 3 & 2868 & 3 & 956 \\
\hline I-435 N @ 23RD STREET & & 3142 & & 1047 \\
\hline Average & & 425 & & 142 \\
\hline Standard Deviation & & & \\
\hline
\end{tabular}

\section{- Three-Lanes Rain and Incidents Measured Within Lane Closure}

The observed discharge flow during incidents and rain for three-lane freeways are shown in Table 28. The traffic data were retrieved from the detectors located on I-35, I-470, I-70, I-635, and I-670. The average capacity was $3,084 \mathrm{veh} / \mathrm{hr}$. Also, the average capacity per open lane was found to be $1,235 \mathrm{veh} / \mathrm{hr} / \mathrm{ln}$. 
Table 28 Rain and Incidents Capacity for Three-Lane (Within Closure)

\begin{tabular}{|l|c|c|c|c|}
\hline \multicolumn{1}{|c|}{ Detector } & $\begin{array}{c}\text { Number } \\
\text { of } \\
\text { Lanes }\end{array}$ & $\begin{array}{c}\text { Discharge Flow } \\
\text { (veh/hr) }\end{array}$ & $\begin{array}{c}\text { Number of } \\
\text { Open Lanes }\end{array}$ & $\begin{array}{c}\text { Discharge Flow per } \\
\text { open lane (veh/hr/ln) }\end{array}$ \\
\hline I-35 N @ NORTH OF MILL ST & 3 & 3372 & 2 & 1686 \\
\hline I-470 E @ VIEW HIGH ROAD & 3 & 2592 & 2 & 1296 \\
\hline I-70 W @ 23RD ST & 3 & 2280 & 2 & 1140 \\
\hline I-35 N @ 75TH ST & 3 & 2304 & 2 & 1152 \\
\hline I-435 S @ SOUTH OF 210 & 3 & 3396 & 2 & 1698 \\
\hline HIGHWAY & 3 & 2352 & 2 & 1176 \\
\hline I-435 S @ PARVIN ROAD & 3 & 2676 & 2 & 1338 \\
\hline I-435 E @ AT 350 HWY & 2 & 2052 & 2 & 1026 \\
\hline I-635 S @ NORTH OF MERRIAM & 3 & 2028 & 2 & 1014 \\
\hline I-70 E @ 27TH ST & 3 & 1956 & 2 & 1068 \\
\hline I-635 N @ DOUGLAS AVE & 3 & 2136 & 2 & 960 \\
\hline I-435 E @ NORTH OF 83RD ST & 3 & 1920 & 2 & 1140 \\
\hline I-70 W @ 23RD ST & 3 & 2280 & 2 & 1314 \\
\hline I-35 S @ PRAIRE STREET & 3 & 2628 & 2 & 1542 \\
\hline I-435 S @ PARVIN ROAD & 3 & 3084 & 2 & 1235 \\
\hline I-670 W @ PAST CHARLOTTE & & 2470 & & 242 \\
\hline Average & & 485 & & \\
\hline Standard Deviation & & & 2 \\
\hline
\end{tabular}

Table 29 shows the results from the t-test. Using a 95\% confidence interval, the resulting twotailed p-value indicated a significant difference between capacities during incidents and rain measured upstream and within the closure.

Table 29 Three-Lanes T-Statistic Between Incidents during Rain Upstream and Within Lane Closure

\begin{tabular}{|c|c|c|}
\hline \multicolumn{2}{|c|}{ Capacity } \\
\hline Category & $\begin{array}{c}\text { Incidents Measured } \\
\text { Upstream of Closure }\end{array}$ & $\begin{array}{c}\text { Incidents Measured } \\
\text { Within Closure }\end{array}$ \\
\hline Mean & 1047 & 1235 \\
\hline $\mathrm{N}$ & 11 & 15 \\
\hline Std. Deviation & 142 & 242 \\
\hline Std. Error Mean & 43 & 62 \\
\hline
\end{tabular}




\begin{tabular}{|c|c|c|c|}
\cline { 2 - 4 } \multicolumn{1}{c|}{} & $\begin{array}{c}\text { Degree of } \\
\text { Freedom }\end{array}$ & T-score & P value (2-tailed) \\
\hline $\begin{array}{c}\text { Incidents upstream closure- } \\
\text { incidents within closure }\end{array}$ & 24 & 2.2956 & 0.0307 \\
\hline
\end{tabular}

As the difference between incident capacities measured upstream and within the closure is considered to be statistically significant, the null hypothesis is rejected. Thus, the effect of incidents by measurement location is meaningful, and the results from Table 27 and Table 28 are different.

\section{- Four-Lanes Rain and Incidents Measured Upstream of Lane Closure}

The twelve detectors, shown in Table 30 and located on I-35, I-435, and I-635, collected the traffic data for incidents during rain measured upstream of a lane closure. The average capacity was 4,702 veh/hr. Also, the average per open lane capacity was 1,176 veh/hr/ln.

Table 30 Rain and Incidents Capacity for Four-Lane (Upstream of Closure)

\begin{tabular}{|l|c|c|c|c|}
\hline \multicolumn{1}{|c|}{ Detector } & $\begin{array}{c}\text { Number } \\
\text { of Lanes }\end{array}$ & $\begin{array}{c}\text { Discharge } \\
\text { Flow (veh/hr) }\end{array}$ & $\begin{array}{c}\text { Number of Open } \\
\text { Lanes }\end{array}$ & $\begin{array}{c}\text { Discharge Flow per open } \\
\text { lane (veh/hr/ln) }\end{array}$ \\
\hline I-35 S @ JOHNSON DR & 4 & 5292 & 4 & 1323 \\
\hline I-435 E @ AT 104TH ST & 4 & 5064 & 4 & 1266 \\
\hline I-35 S @ ANTIOCH RD & 4 & 4320 & 4 & 1080 \\
\hline I-35 S @ West Pennway & 4 & 4368 & 4 & 990 \\
\hline I-635 S @ High Drive & 4 & 3960 & 4 & 1095 \\
\hline I-35 S @ ANTIOCH RD & 4 & 4380 & 4 & 1050 \\
\hline I-35 S @ North of & 4 & 4200 & 4 & 894 \\
ANTIOCH RD & 4 & 3576 & 4 & 1197 \\
\hline I-35 S @ ANTIOCH RD & 4 & 4788 & 4 & 1380 \\
\hline I-35 N@ West Pennway & 4 & 5520 & 4 & 1302 \\
\hline I-435 W @ AT 104TH ST & 4 & 5748 & 4 & 1176 \\
\hline I-35 N @ ANTIOCH RD & 4 & 5208 & 4 & 167 \\
\hline I-35 S @ 67TH ST & & 4702 & & \\
\hline Average & & 670 & & \\
\hline Standard Deviation & & & 4 & \\
\hline
\end{tabular}




\section{- Four-Lanes Rain and Incidents Measured Within Lane Closure}

Average discharge flow at four-lane segments with incidents during rain measured within the lane closure, are presented in Table 31. The average discharge flow (i.e., capacity) was 3,446 $\mathrm{veh} / \mathrm{hr}$. The average capacity per open lane was $1,149 \mathrm{veh} / \mathrm{hr} / \mathrm{ln}$.

Table 31 Rain and Incidents Capacity for Four-Lane (Within Closure)

\begin{tabular}{|c|c|c|c|c|}
\hline Detector & $\begin{array}{c}\text { Number } \\
\text { of } \\
\text { Lanes } \\
\end{array}$ & $\begin{array}{l}\text { Discharge } \\
\text { Flow (veh/hr) }\end{array}$ & $\begin{array}{l}\text { Number of } \\
\text { Open Lanes }\end{array}$ & $\begin{array}{l}\text { Discharge Flow per open } \\
\text { lane }(\mathrm{veh} / \mathrm{hr} / \mathrm{ln})\end{array}$ \\
\hline I-35 S@75TH ST & 4 & 3612 & 3 & 1204 \\
\hline I-470 W@ @ BLUE RIDGE BLVD & 4 & 3252 & 3 & 1084 \\
\hline $\begin{array}{l}\text { I-635 S@ NORTH OF } \\
\text { MERRIAM }\end{array}$ & 4 & 3168 & 3 & 1056 \\
\hline I-35 S@ANTIOCH RD & 4 & 4788 & 3 & 1596 \\
\hline I-435 E@EAST OF HWY69 & 4 & 3348 & 3 & 1116 \\
\hline I-435 E@ INDIAN CREEK & 4 & 3456 & 3 & 1152 \\
\hline I-435 E@STATE LINE RD & 4 & 3288 & 3 & 1096 \\
\hline I-35 S@ANTIOCH RD & 4 & 2700 & 3 & 900 \\
\hline I-70E@18TH STREET & 4 & 3060 & 3 & 1020 \\
\hline I-470 W@BLUE RIDGE BLVD & 4 & 3192 & 3 & 1064 \\
\hline I-70W@ I-470 & 4 & 3480 & 3 & 1160 \\
\hline $\begin{array}{l}\text { I-35 S@63RD ST / SHAWNEE } \\
\text { MI }\end{array}$ & 4 & 4008 & 3 & 1336 \\
\hline $\begin{array}{l}\text { I-35 S @ NORTH OF ANTIOCH } \\
\text { RD }\end{array}$ & 4 & 2868 & 3 & 956 \\
\hline I-35 N@WEST PENNWAY & 4 & 3600 & 3 & 1200 \\
\hline I-35 N@67TH ST & 4 & 3864 & 3 & 1288 \\
\hline Average & & 3446 & & 1149 \\
\hline Standard Deviation & & 507 & & 169 \\
\hline
\end{tabular}

T-test was carried out to measure the difference between rain and incidents, as shown in Table

32. The resultant two-tailed p-value equals 0.6819 , which is greater than 0.05 . Thus, there is no statistical difference between the two capacities. 
Table 32 Four-Lanes T-Statistic Between Incidents during Rain Measured Upstream and Within the Lane Closure

\begin{tabular}{|c|c|c|}
\hline \multicolumn{3}{|c|}{ Capacity } \\
\hline Category & $\begin{array}{c}\text { Incidents Measured } \\
\text { Upstream of Closure }\end{array}$ & $\begin{array}{c}\text { Incidents Measured } \\
\text { Within Closure }\end{array}$ \\
\hline Mean & 1176 & 1149 \\
\hline N & 12 & 15 \\
\hline Std. Deviation & 167 & 169 \\
\hline Std. Error Mean & 48 & 44 \\
\hline
\end{tabular}

\begin{tabular}{|c|c|c|c|}
\cline { 2 - 4 } \multicolumn{1}{c|}{} & $\begin{array}{c}\text { Degree of } \\
\text { Freedom }\end{array}$ & T-score & P value (2-tailed) \\
\hline $\begin{array}{c}\text { Incidents upstream closure- } \\
\text { incidents within closure }\end{array}$ & 25 & 0.4147 & 0.6819 \\
\hline
\end{tabular}

The two-tailed p-value indicated that there was no difference between the results from Table 30 and Table 31. As a result, a new table (Table 33) was developed to combine the observations in terms of four-lanes incidents during rain. The average per lane discharge flow for the combined data was $1,161 \mathrm{veh} / \mathrm{hr} / \mathrm{ln}$.

Table 33 Four-Lanes Incidents and Rain Capacity

\begin{tabular}{|l|c|c|}
\hline Detector & $\begin{array}{c}\text { Number of } \\
\text { Lanes }\end{array}$ & $\begin{array}{c}\text { Discharge Flow per open } \\
\text { lane }(\text { veh/hr/ln) }\end{array}$ \\
\hline I-35 S @ JOHNSON DR & 4 & 1323 \\
\hline I-435 E @ AT 104TH ST & 4 & 1266 \\
\hline I-35 S @ ANTIOCH RD & 4 & 1080 \\
\hline I-35 S @ WEST PENNWAY & 4 & 1092 \\
\hline I-635 S @ HIGH DRIVE & 4 & 990 \\
\hline I-35 S @ ANTIOCH RD & 4 & 1095 \\
\hline I-35 S @ NORTH OF ANTIOCH & 4 & 1050 \\
\hline RD & 4 & 894 \\
\hline I-35 S @ ANTIOCH RD & 4 & 1197 \\
\hline I-35 N @ WEST PENNWAY & 4 & 1380 \\
\hline I-435 W @ AT 104TH ST & 4 & 1437 \\
\hline I-35 N @ ANTIOCH RD & 4 & 1302 \\
\hline I-35 S @ 67TH ST & 4 & 1204 \\
\hline I-35 S @ 75TH ST & 4 & 1084 \\
\hline I-470 W @ BLUE RIDGE BLVD & & \\
\hline
\end{tabular}




\begin{tabular}{|l|c|c|} 
I-635 S @ NORTH OF MERRIAM & 4 & 1056 \\
\hline I-35 S @ ANTIOCH RD & 4 & 1596 \\
\hline I-435 E @ EAST OF HWY 69 & 4 & 1116 \\
\hline I-435 E @ INDIAN CREEK & 4 & 1152 \\
\hline I-435 E @ STATE LINE RD & 4 & 1096 \\
\hline I-35 S @ ANTIOCH RD & 4 & 900 \\
\hline I-70 E @ 18TH STREET & 4 & 1020 \\
\hline I-470 W @ BLUE RIDGE BLVD & 4 & 1064 \\
\hline I-70 W @ I-470 & 4 & 1160 \\
\hline I-35 S @ 63RD ST / SHAWNEE MI & 4 & 1336 \\
\hline I-35 S @ NORTH OF ANTIOCH & 4 & 956 \\
RD & 4 & 1200 \\
\hline I-35 N @ WEST PENNWAY & 4 & 1288 \\
\hline I-35 N @ 67TH ST & & 1161 \\
\hline Average & & 166 \\
\hline Standard Deviation & & \\
\hline
\end{tabular}

In summary, the measurement location resulted in significant differences for the two-lane and three-lane freeways, but not for the four-lane freeways.

\subsection{Free-Flow Speed Results}

The average free-flow speed was observed from the same locations used previously for the capacity measurements. The results are listed in Table 34 as follows.

1- FFS for base conditions

2- FFS during incidents (good weather)

3- FFS during adverse weather (rain and no incidents)

4- FFS for adverse weather (Rain), and incidents

Two sample t-tests were carried out to investigate the difference in the FFS between incidents measured upstream of the closure and within the closure at the study locations. The measurement location was not found to affect FFS during incidents, or incidents with rain, irrespective of the number of lanes. As a result, incidents measured upstream and within the closure were combined 
in Table 34. For example, the average three-lanes FFS during incidents was $62 \mathrm{mph}$. Similarly, the average FFS for four-lane freeways during rain and incidents was $53 \mathrm{mph}$.

Table 34 Observed Free-Flow Speed

\begin{tabular}{|l|c|c|c|}
\hline \multicolumn{1}{|c|}{ FFS (mph) } & $\begin{array}{c}\text { St. Dev } \\
\text { (mph) }\end{array}$ & $\begin{array}{c}\text { Number of } \\
\text { Observations }\end{array}$ \\
\hline 2-lanes & & & \\
3-lanes & 68.2 & 5.3 & 29 \\
4-lanes & 65.1 & 4.2 & 47 \\
\hline Incidents & 62.6 & 2.7 & 22 \\
\hline 2-lanes & & & \\
3-lanes & 61.6 & 7.6 & 17 \\
4-lanes & 61.9 & 5.5 & 43 \\
\hline Adverse Weather (rain) & 58.9 & 4.8 & 38 \\
\hline 2-lanes & & & 13 \\
3-lanes & 67.8 & 2.5 & 20 \\
4-lanes & 61.5 & 4.6 & 16 \\
\hline Adverse Weather (Rain) & 63.8 & 4.1 & 14 \\
and Incidents & & & 25 \\
\hline 2-lanes & 62.5 & 6.7 & 26 \\
3-lanes & 60.9 & 5.6 & \\
4-lanes & 52.9 & 5.2 & \\
\hline
\end{tabular}

\subsection{Statistical Analysis for Capacity}

In order to obtain CAF, the average capacities for the base conditions were compared to the capacities for the remaining conditions. The statistical difference between those capacities was investigated first using a 2-tailed t-test, with $95 \%$ confidence intervals. The events were divided into two groups: non-incident scenarios, and incident scenarios. After that, final tables for CAF were presented as a function of adverse weather and no incidents for the no-incident conditions, and as a function of the number of lanes as well as measurement locations for incident conditions. 


\subsubsection{Effect of Adverse Weather on Capacity}

The observed average breakdown flow rates (i.e., capacity) were compared with the base conditions and the adverse weather (rain) and no incident conditions. The following tables show the results of the t-test analysis.

\section{- Two-lanes}

The t-test results are shown in Table 35 . With a 95\% confidence interval, the two-tailed p-value of 0.7360 is greater than 0.025 , which indicated that the difference is considered to be not statistically significant, thus failing to reject the null hypothesis. This means that rain does not impact capacity at two-lane segments.

Table 35 T-Statistic for Two-Lane During Non-Incidents Conditions

\begin{tabular}{|c|c|c|}
\hline \multicolumn{3}{|c|}{ Capacity } \\
\hline Category & Base Conditions & Rain \\
\hline Mean & 1645 & 1624 \\
\hline N & 29 & 13 \\
\hline Std. Deviation & 163 & 229 \\
\hline Std. Error Mean & 30.27 & 63.51 \\
\hline
\end{tabular}

\begin{tabular}{|l|l|l|l|}
\cline { 2 - 4 } \multicolumn{1}{c|}{} & $\begin{array}{l}\text { Degree of } \\
\text { Freedom }\end{array}$ & T-score & $\begin{array}{l}\text { P value } \\
\text { (2-tailed) }\end{array}$ \\
\hline Base Conditions-Rain & 40 & 0.3396 & 0.7360 \\
\hline
\end{tabular}

\section{- Three-Lanes}

The results shown in Table 36 indicated that the difference between the average capacity during base conditions and during rain is considered to be not significant, so the null hypothesis is not rejected. The two-tailed p-value equals 0.2789 , which is higher than 0.025 . As such, rain does not affect capacity of three-lane freeways. 
Table 36 T-Statistic for Three-Lane During Non-Incidents Conditions

\begin{tabular}{|c|c|c|}
\hline \multicolumn{3}{|c|}{ Capacity } \\
\hline Category & Base Conditions & Rain \\
\hline Mean & 1746 & 1693 \\
\hline N & 47 & 20 \\
\hline Std. Deviation & 177 & 193 \\
\hline Std. Error Mean & 25.82 & 43.16 \\
\hline
\end{tabular}

\begin{tabular}{|l|l|l|l|}
\cline { 2 - 4 } \multicolumn{1}{c|}{} & $\begin{array}{l}\text { Degree of } \\
\text { Freedom }\end{array}$ & T-score & $\begin{array}{l}\text { P value } \\
\text { (2-tailed) }\end{array}$ \\
\hline Base Conditions-Rain & 65 & 1.0918 & 0.2789 \\
\hline
\end{tabular}

\section{- Four-Lane}

The results shown in Table 37 indicate that the difference between base and rain conditions is not significant at four-lane segments. The two-tailed p-value equals 0.8962 which is greater than 0.025. As a result, the null hypothesis could not be rejected.

Table 37 T-Statistic for Four-Lane During Non-Incidents Conditions

\begin{tabular}{|c|c|c|}
\hline \multicolumn{3}{|c|}{ Capacity } \\
\hline Category & Base Conditions & Rain \\
\hline Mean & 1633 & 1626 \\
\hline $\mathrm{N}$ & 22 & 16 \\
\hline Std. Deviation & 160 & 165 \\
\hline Std. Error Mean & 34.11 & 41.25 \\
\hline
\end{tabular}

\begin{tabular}{|l|l|l|l|}
\cline { 2 - 4 } \multicolumn{1}{c|}{} & $\begin{array}{l}\text { Degree of } \\
\text { Freedom }\end{array}$ & T-score & $\begin{array}{l}\text { P value } \\
\text { (2-tailed) }\end{array}$ \\
\hline Base Conditions-Rain & 36 & 0.1314 & 0.8962 \\
\hline
\end{tabular}

In summary, rain did not result in statistically significant capacity differences in two-, three-, or four-lane segments; therefore, CAFs cannot be estimated based on the data analyzed in this research.

\subsubsection{Effect of Incidents on Capacity}

As a function of the number of lanes, as well as measurement location, a two-tailed t-test was carried out to identify the significance level between the different incident's conditions. The 
average base capacity was compared to the average incidents during good weather and then compared to rain with incident conditions. As it was discussed earlier, the average breakdown flow was used to measure the base capacity, while the average discharge flow was used to measure the incidents capacity. However, to analyze the base conditions and incidents conditions accurate, the average discharge flow observed during base conditions was compared to the average discharge flow for incident conditions. Also, the average discharge flow during the base conditions for two-, three- and four-lane freeways was found to be $1570 \mathrm{veh} / \mathrm{hr} / \mathrm{ln}, 1577$ $\mathrm{veh} / \mathrm{hr} / \mathrm{ln}$ and 1517 , respectively. The measurement location during good weather incidents was not considered for two, three, and four lanes as the statistical analysis showed no significant differences. On the other hand, the effect of measurement location for incidents and rain conditions was considered for two- and three-lane segments, while it was not measured for fourlane segments.

\section{- Incident Capacity for Two-Lanes}

Table 38 shows the average discharge flow for four different conditions, and the resulting t-test. The Capacity for base conditions was found to be significantly different compared to the capacities during incidents (and good weather), rain and incidents (measured upstream of closure), and rain and incidents (measured within the closure).

Table 38 T-Statistic for Two-Lane Incidents Capacity

\begin{tabular}{|c|c|c|c|c|}
\hline \multicolumn{5}{|c|}{ Capacity } \\
\hline Category & $\begin{array}{c}\text { Base } \\
\text { Conditions }\end{array}$ & $\begin{array}{c}\text { Incidents } \\
\text { (Good Weather) }\end{array}$ & $\begin{array}{l}\text { Rain and incidents } \\
\text { (upstream of } \\
\text { closure) }\end{array}$ & $\begin{array}{l}\text { Rain and Incidents } \\
\text { (within closure) }\end{array}$ \\
\hline Mean & 1570 & 1102 & 1057 & 1436 \\
\hline $\mathrm{N}$ & 29 & 18 & 10 & 6 \\
\hline Std. Deviation & 108 & 244 & 195 & 208 \\
\hline Std. Error Mean & 20 & 58 & 62 & 85 \\
\hline
\end{tabular}




\begin{tabular}{|c|c|c|c|}
\cline { 2 - 4 } \multicolumn{1}{c|}{} & $\begin{array}{c}\text { Degree of } \\
\text { Freedom }\end{array}$ & T-score & P value (2-tailed) \\
\hline $\begin{array}{c}\text { Base Conditions- Incidents } \\
\text { (Good Weather) }\end{array}$ & 45 & 9.0427 & 0.000 \\
\hline
\end{tabular}

\begin{tabular}{|c|c|c|c|}
\cline { 2 - 4 } \multicolumn{1}{c|}{} & $\begin{array}{c}\text { Degree of } \\
\text { Freedom }\end{array}$ & T-score & P value (2-tailed) \\
\hline $\begin{array}{c}\text { Base Conditions- Rain and } \\
\text { Incidents (upstream of } \\
\text { closure) }\end{array}$ & 37 & 10.4047 & 0.000 \\
\hline
\end{tabular}

\begin{tabular}{|c|c|c|c|}
\cline { 2 - 4 } \multicolumn{1}{c|}{} & $\begin{array}{c}\text { Degree of } \\
\text { Freedom }\end{array}$ & T-score & P value (2-tailed) \\
\hline $\begin{array}{c}\text { Base Conditions - Rain and } \\
\text { Incidents (within closure) }\end{array}$ & 33 & 2.3294 & 0.013 \\
\hline
\end{tabular}

In summary, the statistical analysis indicated that incidents during good weather and incidents during rain, measured upstream or within the lane closure, had an effect on capacity for two-lane freeways.

\section{- Incident Capacity for Three-Lanes}

In this section, the average discharge flow from the base conditions was compared to the average discharge flow from the incidents during good weather conditions. Also, incidents and rain by measurement location were considered in three lanes capacity, while the average of base conditions was compared twice, both to incidents measured upstream of closure and incidents measured within the closure, as seen in Table 39. The results from the t-test indicated significant difference among the four conditions. 
Table 39 T-Statistic for Three-Lane Incidents Capacity

\begin{tabular}{|c|c|c|c|c|}
\hline \multicolumn{5}{|c|}{ Capacity } \\
\hline Category & $\begin{array}{c}\text { Base } \\
\text { Conditions }\end{array}$ & $\begin{array}{c}\text { Incidents } \\
\text { (Good Weather) }\end{array}$ & $\begin{array}{c}\text { Rain and incidents } \\
\text { (Upstream of } \\
\text { Closure) }\end{array}$ & $\begin{array}{c}\text { Rain and Incidents } \\
\text { (Within Closure) }\end{array}$ \\
\hline Mean & 1577 & 1304 & 1047 & 1235 \\
\hline N & 47 & 44 & 11 & 15 \\
\hline Std. Deviation & 168 & 231 & 142 & 242 \\
\hline Std. Error Mean & 25 & 35 & 43 & 63 \\
\hline
\end{tabular}

\begin{tabular}{|c|c|c|c|}
\cline { 2 - 4 } \multicolumn{1}{c|}{} & $\begin{array}{c}\text { Degree of } \\
\text { Freedom }\end{array}$ & T-score & P value (2-tailed) \\
\hline $\begin{array}{c}\text { Base Conditions- Incidents } \\
\text { (Good Weather) }\end{array}$ & 89 & 6.4773 & 0.000 \\
\hline
\end{tabular}

\begin{tabular}{|c|c|c|c|}
\cline { 2 - 4 } \multicolumn{1}{c|}{} & $\begin{array}{c}\text { Degree of } \\
\text { Freedom }\end{array}$ & T-score & P value (2-tailed) \\
\hline $\begin{array}{c}\text { Base Conditions- Rain and } \\
\text { Incidents (upstream of } \\
\text { closure) }\end{array}$ & 56 & 9.6686 & 0.000 \\
\hline $\begin{array}{c}\text { Base Conditions - Rain and } \\
\text { Incidents (within closure) }\end{array}$ & 60 & 6.1379 & 0.000 \\
\hline
\end{tabular}

The t-test analysis asserted the effect of incidents on three-lanes capacity. Incidents during base weather, as well as incidents during rain, had an impact on the capacity at three lane freeways.

\section{- Incident Capacity for Four-lanes}

Unlike two- and three-lane freeways, the measurement location was not found to affect capacity during rain and incidents at four-lane freeways. Additionally, the measurement location did not affect the good weather incidents capacity at four-lane freeways. Thus, average discharge flow from the base condition was compared to incidents capacity, as well as the capacity under rain and incidents conditions, without taking into account the measurement location (Table 40). 
The results indicated a significant difference between the capacities as the resulting p-value was less than 0.0001 . Also, the comparison between the base condition and rain with incidents resulted in a p-value of less than 0.025 .

Table 40 T-Statistic for Four-Lane Incidents

\begin{tabular}{|c|c|c|c|}
\hline \multicolumn{3}{|c|}{ Capacity } \\
\hline Category & $\begin{array}{c}\text { Base } \\
\text { Conditions }\end{array}$ & $\begin{array}{c}\text { Good Weather } \\
\text { (with Incidents) }\end{array}$ & $\begin{array}{c}\text { Rain and } \\
\text { Incidents }\end{array}$ \\
\hline Mean & 1517 & 1257 & 1161 \\
\hline N & 22 & 39 & 27 \\
\hline Std. Deviation & 127 & 157 & 166 \\
\hline Std. Error Mean & 27 & 25 & 32 \\
\hline
\end{tabular}

\begin{tabular}{|c|c|c|c|}
\cline { 2 - 4 } \multicolumn{1}{c|}{} & $\begin{array}{c}\text { Degree of } \\
\text { Freedom }\end{array}$ & T-score & P value (2-tailed) \\
\hline $\begin{array}{c}\text { Base Conditions- Incidents } \\
\text { (Good Weather) }\end{array}$ & 59 & 6.6322 & 0.000 \\
\cline { 2 - 5 } \multicolumn{2}{c}{$\begin{array}{c}\text { Degree of } \\
\text { Freedom }\end{array}$} & T-score & P value (2-tailed) \\
\hline $\begin{array}{c}\text { Base Conditions- Rain and } \\
\text { Incidents }\end{array}$ & 47 & 8.2724 & 0.000 \\
\hline
\end{tabular}

According to the statistical analysis results shown in Table 38, Table 39, and Table 40, an effect of incidents on capacity was found. Good weather incidents had an impact on the capacity of two, three, and four lanes. Also, rain and incidents at two- and three-lane freeways, affected the capacity. Likewise, incidents, as well as incidents and rain had an impact on four-lane capacity.

\subsection{Statistical Analysis for Free-Flow Speed}

This part provides the results of the statistical analysis for FFS. T-tests were carried out to examine the effect of rain (no incidents) and incidents conditions on Free-Flow Speed.

\subsubsection{Effect of Adverse Weather on Free-Flow Speed}

In this section, the observed Free-Flow Speed during base conditions was compared to the FreeFlow Speed during rain without any incidents. T-test was used to assess the difference between the two conditions, and a 95\% significance level was used throughout the statistical analysis. 


\section{- Two-Lanes}

Table 41 shows the results of the statistical analysis. The two-tailed p-value is equal to 0.7976 , which indicated no difference in FFS between base conditions and rain without any incidents.

Table 41 T-Statistic for Two-Lane During Adverse Weather (Rain)

\begin{tabular}{|c|c|c|}
\hline & FFS & \\
\hline Category & Base Conditions & Rain \\
\hline Mean & 68.2 & 67.8 \\
\hline N & 29 & 13 \\
\hline Std. Deviation & 5.3 & 2.5 \\
\hline Std. Error Mean & 0.98 & 0.693 \\
\hline
\end{tabular}

\begin{tabular}{|c|c|c|c|}
\cline { 2 - 4 } \multicolumn{1}{c|}{} & $\begin{array}{c}\text { Degree of } \\
\text { Freedom }\end{array}$ & T-score & $\begin{array}{c}\text { P value } \\
\text { (2-tailed) }\end{array}$ \\
\hline Base Conditions-Rain & 40 & 0.2582 & 0.7976 \\
\hline
\end{tabular}

- Three-Lanes

The resultant two-tailed p-value equaling 0.0027 indicated that the difference is considered to be statistically significant, at $p<0.05$, between the base conditions and rain without incidents at the three-lane freeways, as demonstrated in Table 42.

Table 42 T-Statistic for Three-Lane During Adverse Weather (Rain)

\begin{tabular}{|c|c|c|}
\hline \multicolumn{3}{|c|}{ FFS } \\
\hline Category & Base Conditions & Rain \\
\hline Mean & 65.1 & 61.5 \\
\hline $\mathrm{N}$ & 47 & 20 \\
\hline Std. Deviation & 4.2 & 4.6 \\
\hline Std. Error Mean & 0.613 & 1.03 \\
\hline
\end{tabular}

\begin{tabular}{|c|c|c|c|}
\cline { 2 - 4 } \multicolumn{1}{c|}{} & $\begin{array}{c}\text { Degree of } \\
\text { Freedom }\end{array}$ & T-score & $\begin{array}{c}\text { P value } \\
\text { (2-tailed) }\end{array}$ \\
\hline Base Conditions-Rain & 65 & 3.1208 & 0.0027 \\
\hline
\end{tabular}




\section{- Four-Lanes}

Table 43 shows the t-test results of average FFS during the base conditions and the average FFS during rain without incident conditions. The observed p-value equals 0.2863 which is greater than 0.025 . As a result, the difference in this case is considered to be not statistically significant.

Table 43 T-Statistic for Four-Lane During Adverse Weather (Rain)

\begin{tabular}{|c|c|c|}
\hline \multicolumn{3}{|c|}{ FFS } \\
\hline Category & Base Conditions & Rain \\
\hline Mean & 62.6 & 63.8 \\
\hline $\mathrm{N}$ & 22 & 16 \\
\hline Std. Deviation & 2.7 & 4.1 \\
\hline Std. Error Mean & 0.58 & 1.025 \\
\hline
\end{tabular}

\begin{tabular}{|c|c|c|c|}
\cline { 2 - 4 } \multicolumn{1}{c|}{} & $\begin{array}{c}\text { Degree of } \\
\text { Freedom }\end{array}$ & T-score & $\begin{array}{c}\text { P value } \\
\text { (2-tailed) }\end{array}$ \\
\hline Base Conditions-Rain & 36 & 1.0886 & 0.2863 \\
\hline
\end{tabular}

The statistical analysis of this section demonstrated that only Free-Flow Speed on the three-lanes facility was affected by adverse weather (rain) conditions. Nevertheless, adverse weather did not have an impact on Free-Flow Speed on two and four lanes freeways.

\subsubsection{Effect of Incident on Free-Flow Speed}

Incidents Free-Flow Speed was observed during rain, as well as during good weather conditions. As discussed previously, the difference between FFS during Incidents measured upstream of a lane closure and FFS during Incidents measured within the Lane Closure were statistically insignificant for two-, three-, and four-lane freeways. Thus, incidents by measurement location were not considered for this analysis. In this section, T-test was carried out, with a confidence interval of $95 \%$, between the average FFS during Base Conditions and Incidents FFS during Good Weather conditions. Similarly, FFS during incidents and rain was compared to FFS during base conditions. 


\section{- Incidents Free-Flow Speed at Two-Lanes}

As indicated in Table 44, the difference between the average FFS from the Base Conditions and Incidents with Good Weather resulted in a two-tailed p-value of 0.0012 , which is less than 0.025 . This finding indicated that the difference is considered to be statistically significant at $p<0.05$. Thus, the null hypothesis was rejected. Furthermore, the relationship between FFS during base conditions and FFS during rain and incidents reflected a statistical significance. The pulled pvalue from the two-tailed t-test was found to be 0.0042 , which is less than 0.025 .

Table 44 T-Statistics for Two-Lane Incident FFS

\begin{tabular}{|c|c|c|c|}
\hline \multicolumn{4}{|c|}{ Two-Lanes FFS } \\
\hline Category & $\begin{array}{c}\text { Base } \\
\text { Conditions }\end{array}$ & $\begin{array}{c}\text { Good Weather } \\
\text { (Incidents) }\end{array}$ & $\begin{array}{c}\text { Rain and } \\
\text { Incidents }\end{array}$ \\
\hline Mean & 68.2 & 61.6 & 62.5 \\
\hline $\mathrm{N}$ & 29 & 17 & 14 \\
\hline Std. Deviation & 5.3 & 7.6 & 6.7 \\
\hline Std. Error Mean & 0.98 & 1.84 & 1.8 \\
\hline
\end{tabular}

\begin{tabular}{|c|c|c|c|}
\cline { 2 - 4 } \multicolumn{1}{c|}{} & $\begin{array}{c}\text { Degree of } \\
\text { Freedom }\end{array}$ & T-score & P value (2-tailed) \\
\hline $\begin{array}{c}\text { Base Conditions- Incidents } \\
\text { (Good Weather) }\end{array}$ & 44 & 3.4652 & 0.0012 \\
\hline
\end{tabular}

\begin{tabular}{|c|c|c|c|}
\cline { 2 - 4 } \multicolumn{1}{c|}{} & $\begin{array}{c}\text { Degree of } \\
\text { Freedom }\end{array}$ & T-score & P value (2-tailed) \\
\hline $\begin{array}{c}\text { Base Conditions- Rain and } \\
\text { Incidents }\end{array}$ & 41 & 3.0298 & 0.0042 \\
\hline
\end{tabular}

Based on the results shown in Table 44, incidents affected FFS on two-lanes. The t-test indicated that FFS was impacted by incidents during good weather on two-lane freeways. Incidents and rain also influenced FFS on two-lane freeways. 


\section{- Incidents Free-Flow Speed at Three-Lanes}

The difference between the conditions presented in Table 45 was found to be significant. The pvalue from the relationship between base conditions and incidents during Good Weather was 0.0025, which is less than 0.025 . Likewise, the two-tailed p-value from the difference between the base conditions and incidents during rain was 0.0006 , which indicates a significant difference between them.

Table 45 T-Statistics for Three-Lane Incident FFS

\begin{tabular}{|c|c|c|c|}
\hline \multicolumn{4}{|c|}{ Three-Lanes FFS } \\
\hline Category & $\begin{array}{c}\text { Base } \\
\text { Conditions }\end{array}$ & $\begin{array}{c}\text { Good Weather } \\
\text { (Incidents) }\end{array}$ & $\begin{array}{c}\text { Rain and } \\
\text { Incidents }\end{array}$ \\
\hline Mean & 65.1 & 61.9 & 60.9 \\
\hline $\mathrm{N}$ & 47 & 43 & 25 \\
\hline Std. Deviation & 4.2 & 5.5 & 5.6 \\
\hline Std. Error Mean & 0.61 & 0.839 & 1.12 \\
\hline
\end{tabular}

\begin{tabular}{|c|c|c|c|}
\cline { 2 - 4 } \multicolumn{1}{c|}{} & $\begin{array}{c}\text { Degree of } \\
\text { Freedom }\end{array}$ & T-score & P value (2-tailed) \\
\hline $\begin{array}{c}\text { Base Conditions- Incidents } \\
\text { (Good Weather) }\end{array}$ & 88 & 3.1176 & 0.0025 \\
\hline
\end{tabular}

\begin{tabular}{|c|c|c|c|}
\cline { 2 - 4 } \multicolumn{1}{c|}{} & $\begin{array}{c}\text { Degree of } \\
\text { Freedom }\end{array}$ & T-score & P value (2-tailed) \\
\hline $\begin{array}{c}\text { Base Conditions- Rain and } \\
\text { Incidents }\end{array}$ & 70 & 3.5894 & 0.0006 \\
\hline
\end{tabular}

Finally, the above results demonstrated the effect of incidents on FFS at three-lane freeways. Incidents during good weather, as well as incidents during rain affected FFS at three-lane segments. 


\section{- Incidents Free-Flow Speed at Four-Lanes}

T-test was used to compare the average FFS during different conditions at four-lane freeways.

The outcomes specified that the differences are considered statistically significant between all the conditions that were compared (Table 46).

Table 46 T-Statistic for Four-Lane Incidents FFS

\begin{tabular}{|c|c|c|c|}
\hline \multicolumn{4}{|c|}{ Four-Lanes FFS } \\
\hline Category & $\begin{array}{c}\text { Base } \\
\text { Conditions }\end{array}$ & $\begin{array}{c}\text { Good Weather } \\
\text { (Incidents) }\end{array}$ & $\begin{array}{c}\text { Rain and } \\
\text { Incidents }\end{array}$ \\
\hline Mean & 62.6 & 58.9 & 52.9 \\
\hline $\mathrm{N}$ & 22 & 38 & 26 \\
\hline Std. Deviation & 2.7 & 4.8 & 5.2 \\
\hline Std. Error Mean & 0.576 & 0.779 & 1.02 \\
\hline
\end{tabular}

\begin{tabular}{|c|c|c|c|}
\cline { 2 - 4 } \multicolumn{1}{c|}{} & $\begin{array}{c}\text { Degree of } \\
\text { Freedom }\end{array}$ & T-score & P value (2-tailed) \\
\hline $\begin{array}{c}\text { Base Conditions- Incidents } \\
\text { (Good Weather) }\end{array}$ & 58 & 3.3169 & 0.0016 \\
\hline
\end{tabular}

\begin{tabular}{|c|c|c|c|}
\cline { 2 - 4 } \multicolumn{1}{c|}{} & $\begin{array}{c}\text { Degree of } \\
\text { Freedom }\end{array}$ & T-score & P value (2-tailed) \\
\hline $\begin{array}{c}\text { Base Conditions- Rain and } \\
\text { Incidents }\end{array}$ & 46 & 7.8873 & 0.0001 \\
\hline
\end{tabular}

The effect of incidents on FFS was meaningful for four-lane freeways. Good weather incidents, as well as incidents during rain according to the statistical analysis shown in Table 46, affected the FFS on four-lane freeways.

\subsubsection{Conclusions}

The process of obtaining capacity and FFS involved comparing the average capacity as well as FFS during base conditions to the remaining conditions that included incidents, rain without incidents, and incidents during rain. It was essential to statistically examine the differences between those conditions before developing the CAFs and SAFs. Thus, t-tests were carried out and the results were as follows. 
1- Capacity:

Comparison between capacity under base conditions and capacity under adverse weather showed no significant difference, therefore, it can be assumed that rain did not affect capacity at the study locations.

For the effect of incidents on capacity, the statistical analysis showed that incidents affected capacity at all freeway segments. Rain and incidents also affected capacity for all segments studied. Under these conditions, the measurement location was also found to affect capacity at two-lane and three-lane segments.

2- Free-Flow Speed:

Adverse weather (rain) had a negative impact on FFS on three-lane freeways only. Incidents (assuming good weather) as well as incidents under rain also affected FFS for all study segments. The measurement location during incidents was not found to significantly impact FFS.

\subsection{Capacity and Free-Flow Speed Adjustment Factors}

In this section, the final results of the Capacity Adjustment Factors (CAF) and the Speed Adjustment Factors (SAF) are presented. The results involve the impact of rain, incidents, and incidents with rain conditions.

\subsubsection{Capacity Adjustment Factors (CAF) for Adverse Weather (Rain)}

The statistical analysis showed no effect of adverse weather (rain) on the capacity for two, three, and four lane segments. Therefore, the remaining capacity (i.e., CAF) due to adverse weather was not quantified in this study.

\subsubsection{Capacity Adjustment Factors (CAF) for Incidents and Incidents with Rain}

Table 47 shows the final CAFs results. The first three CAFs concern incidents during good weather. For example, the remaining capacity during incidents (and good weather) is $70 \%$ of the capacity during base conditions. In addition, the measurement location was considered for 
incidents and rain conditions for two and three lane segments. For instance, capacity during incidents measured within the lane closure and rain at three-lane freeways was reduced by $22 \%$.

Table 47 Capacity Adjustment Factors (CAF) for Incidents and Incidents with Rain by Number of Lanes

\begin{tabular}{|l|c|}
\hline & CAF \\
\hline Incidents & \\
\hline Two-Lanes & 0.70 \\
\hline Three-Lanes & 0.83 \\
\hline Four-Lanes & 0.83 \\
\hline Incidents and Rain & \\
\hline Two-Lanes Upstream of Closure & 0.67 \\
\hline Two-Lanes Within Closure & 0.91 \\
\hline Three-Lanes Upstream of Closure & 0.66 \\
\hline Three-Lanes Within Closure & 0.78 \\
\hline Four-Lanes & 0.77 \\
\hline
\end{tabular}

\subsubsection{Speed Adjustment Factors (SAF) for Adverse Weather}

The statistical analysis showed no effect of adverse weather on FFS on two and four lanes freeway, while the impact was only detected on three lanes freeway, as can be seen in Table 48 . Adverse weather (rain) reduced FFS on three-lanes facilities by 5\%. Thus, the FFS was maintained by $95 \%$ during rain.

Table 48 Speed Adjustment Factor (SAF) for Adverse Weather (Rain)

\begin{tabular}{|l|c|}
\hline \multicolumn{1}{|c|}{ Adverse Weather (Rain) } & FFS Adjustment Factors (SAF) \\
\hline Two-Lane & N/A \\
\hline Three-Lane & 0.95 \\
\hline Four-Lane & N/A \\
\hline
\end{tabular}

\subsubsection{Speed Adjustment Factors (SAF) for Incidents and Incidents with Rain}

Table 49 shows the free-flow speed adjustment factors for incidents and good weather, and incidents and rain. For example, the remaining FFS at two-lane segments when incidents occur was $91 \%$ of the FFS during base conditions. 
Table 49 Speed Adjustment Factors (SAF) for Incidents and Incidents with Rain

\begin{tabular}{|l|c|}
\hline & SAF \\
\hline Incidents & \\
\hline Two-Lanes & 0.90 \\
\hline Three-Lanes & 0.95 \\
\hline Four-Lanes & 0.94 \\
\hline Incidents and Rain & \\
\hline Two-Lanes & 0.92 \\
\hline Three-Lanes & 0.94 \\
\hline Four-Lanes & 0.84 \\
\hline
\end{tabular}




\section{SUMMARY AND CONCLUSIONS}

This section presents a summary of the methods used to obtain the observed capacities and freeflow speeds and adjustment factors. The final results are discussed, and some recommendations are suggested for future studies.

This study focused on estimating the effect of rain and incidents on capacity as well as free-flow speed, using data from Kansas City for the period from 2014 to 2018. KCSCOUT and Weather Underground were the primary resources for the data collection. Four conditions were considered in this thesis: (1) base conditions that did not include incidents or adverse weather, (2) incident conditions during good weather, (3) rain conditions without incidents, and (4) incident conditions during rainy weather. Also, the type of lane closure during incidents was evaluated.

\subsection{Conclusions}

CAFs and SAFs as the function of weather (no incidents) were calculated by comparing the average from the base conditions to the average from rainy conditions. However, the effect of adverse weather (rain) on capacity was not found to be significant, and only FFS at three-lane segments was impacted by rain. SAF for three-lanes during rain without any incidents was 0.95 .

CAFs and SAFs were estimated by comparing the average from the base conditions to the average from incident (during good weather) or incidents during rainy conditions. Overall, incidents, as well as incidents during rain, affected capacity and FFS. Also, the measurement location affected the capacity for incidents during rain at two and three lane segments. Nevertheless, our analysis indicated that incidents by measurement location did not have an impact on good weather incidents at the study locations. The same analysis, also, showed that incidents by measurement location did not have an effect on FFS for two-, three, and four-lanes at the study locations. 
CAFs during incidents (and good weather) were $0.70,0.83$ and 0.83 for two, three, and four lane segments, respectively. CAF for incidents and rain (measured upstream of the lane closure) was $0.67,0.66$, and 0.77 at two-lane, three-lane, and four-lane segments respectively. Incidents and rain affected capacity (measured within the closure) on two-lane and three-lane segments, with CAFs equal to 0.91 and 0.78 , respectively.

While HCM6 (1) did not study the effect of incidents on FFS, this thesis conducted several SAFs for both incidents and incidents during rain. The remaining FFSs when incidents occurred were 0.90 for two-lanes, 0.95 for three-lanes, and 0.94 for four-lanes. Similarly, two, three, and four lanes were able to handle $92 \%, 94 \%$, and $84 \%$, respectively, when both rain and incidents occurred.

\subsection{Recommendations}

This section provides recommendations for future studies.

- The Highway Capacity Manual $6^{\text {th }}$ edition (HCM6) (1), estimated default CAFs as a function of adverse weather (no incidents). However, the results from this thesis indicated no effect of adverse weather on capacity. This may be due to the limited data that were analyzed in this thesis, or the focus on only rain as adverse weather conditions. As such, future studies should focus on analyzing a larger set of data with possibly more adverse weather.

- HCM6 (1) did not study CAFs and SAFs as a function of incidents associated with adverse weather. Their assumption was that incidents and adverse weather are two independent events; therefore, when both happen at the same time the resulting CAF is estimated from the product of the two separate CAFs (1). However, this has not been validated by actual data. Although this research did not find any impact on capacity during adverse weather alone, when incidents occur during rain the capacity drop is more 
severe compared to during incidents only. Therefore, the multiplicative effect of rain and incidents as suggested in the HCM6 was not verified in this thesis.

- Data collection on two-lane segments were challenging due to a lack of related events. Therefore, future study might expand the number of observations for two lane freeways by collecting data at different locations outside of Kansas City or the Kansas City metro area. It is also recommended that future research use other data sources such as RITIS or PeMS that provides a wide range of access to other states freeway data macroscopic flow database and incident records.

- Five-lane freeways were initially considered in this thesis. However, limited data were available on five-lane freeways. Thus, future research should expand on five-lane freeways. This could be done by accessing other data source as mentioned in the previous bullet point.

- It is also recommended to examine the effect of incidents with more than one lane blockage, similar to the HCM6.

The limitations of this study are listed as following:

- One of the limitations of this study is the inability to construct the breakdown probability function during incident or rain. The breakdown probability function gives a more precise idea regarding the probability of a breakdown at a certain flow. Breakdown probability function has been investigated in freeway capacity studies, and it is regarded as a major tool to predict freeway capacity.

- This study does not evaluate the impact of incidents on the fundamental diagram. In other words, Flow-Density and Speed-Flow diagram can be generated for adverse weather or incidents. 
- This study only focused on events that were caused by vehicle-vehicle crashes. Other events types such as stalled vehicle, debris, emergency vehicles, etc. were excluded during the data collection phase.

- Incident time (e.g. initial response, incident clearance, roadway clearance, and time to return to normal condition) was not considered as a factor while evaluating the freeway capacity or FFS. 


\section{References}

1) HCM 2016: highway capacity manual. (2016). Washington, D.C.: Transportation Research Board.

2) HCM 2010: highway capacity manual. (2010). Washington, D.C.: Transportation Research Board.

3) Smith, B. L., Qin, L., \& Venkatanarayana, R. (2003). Characterization of freeway capacity reduction resulting from traffic accidents. Journal of Transportation Engineering, 129(4), 362-368.

4) Chin SM, Franzese O, Greene DL, Hwang HL, Gibson R. (2004). Temporary losses of highway capacity and impacts on performance: Phase 2. United States. Dept. of Energy. Office of Scientific and Technical Information.

5) Lu, C., \& Elefteriadou, L. (2013). An investigation of freeway capacity before and during incidents. Transportation letters, 5(3), 144-153.

6) Kondyli, A., Hale, D. K., Asgharzadeh, M., Schroeder, B., Jia, A., \& Bared, J. (2019). Evaluating the Operational Effect of Narrow Lanes and Shoulders for the Highway Capacity Manual. Transportation Research Record.

7) Rakha, H., Farzaneh, M., Arafeh, M., \& Sterzin, E. (2008). Inclement weather impacts on freeway traffic stream behavior. Transportation Research Record, 2071(1), 8-18.

8) Camacho, F., García, A., \& Belda, E. (2010). Analysis of impact of adverse weather on freeway free-flow speed in Spain. Transportation Research Record: Journal of the Transportation Research Board, (2169), 150-159.

9) Jia, Y., Wu, J., Du, Y., \& Qi, G. (2014). Impacts of rainfall weather on urban traffic in Beijing: analysis and modeling. arXiv preprint arXiv:1407.4522.

10) Singh Dhaliwal, S. (2017). The Effects of Rain on Freeway Traffic in Southern California. Transportation Research Record: Journal of the Transportation Research Board, 2616(1), 69-80.

11) Elefteriadou. (2013). An Introduction to Traffic Flow Theory. New York, NY: SpringerVerlag New York Inc, pp.4-97. 
12) Roess, R. E. Prassas, W. McShane (2011). Traffic Engineering. Upper Saddle River, NJ: Pearson Higher Education, pp. 5-102.

13) Asgharzadeh M., Kondyli A. (2018). Comparison of highway capacity estimation methods. Transportation Research Record, 2672(15), 75-84.

14) Asgharzadeh, M., Kondyli A. (2019). Evaluating the Effect of Geometry and Control on Freeway Merge Bottleneck Capacity. Transportation Research Board. Washington, D.C. 